\title{
Host immune responses to chlamydial inclusion membrane proteins $B$ and $C$ in Chlamydia trachomatis infected women with or without fertility disorders
} Rishein Gupta ${ }^{1}$, Pragya Srivastava ${ }^{1}$, Harsh Vardhan ${ }^{1}$, Sudha Salhan ${ }^{2}$ and Aruna Mittal*1

Address: ${ }^{1}$ Institute of Pathology-ICMR, Safdarjang Hospital Campus, Post Box no. 4909, New Delhi-110 029, India and ${ }^{2}$ Department of Gynaecology \& Obstetrics, Safdarjung Hospital, New Delhi-110 029, India

Email: Rishein Gupta - rishein9@rediffmail.com; Pragya Srivastava - pragyasr@rediffmail.com; Harsh Vardhan - harsh.chlamydia@gmail.com; Sudha Salhan - sudhasalhan@rediffmail.com; Aruna Mittal* - amittal_cp@rediffmail.com

* Corresponding author

Published: 28 April 2009

Reproductive Biology and Endocrinology 2009, 7:38 doi:10.1186/1477-7827-7-38

This article is available from: http://www.rbej.com/content/7/1/38

(C) 2009 Gupta et al; licensee BioMed Central Ltd.

This is an Open Access article distributed under the terms of the Creative Commons Attribution License (http://creativecommons.org/licenses/by/2.0), which permits unrestricted use, distribution, and reproduction in any medium, provided the original work is properly cited.

\begin{abstract}
Background: With an increase in the number of putative inclusion membrane proteins (incs) in chlamydial genomes, there is a need for understanding their contribution in host-pathogen interactions. Thus in this study we determined the host mucosal and peripheral immune responses to incs ( $\operatorname{lncB}$ and $\operatorname{lnc} C$ ) of Chlamydia trachomatis (CT).

Methods: Female patients $(n=296)$ attending the gynaecology out patient department of Safdarjung hospital, New Delhi were enrolled for the study and were clinically characterized into two groups; CT-positive fertile women $(n=38)$ and CT-positive women with fertility disorders $(n=29)$. Uninfected healthy fertile women were enrolled as controls $(n=$ 3I). Gene specific PCRs were used for detection of incB and inc $C$ genes in endocervical samples of CT-positive patients. ELISA and Western blot assay were used for detection of $\lg A$ and $\lg G$ antibodies to $\operatorname{lncB}$ and $\operatorname{lnc} C$ in cervical washes and sera. Effect of IncB and IncC stimulation of cervical cells and PBMCs on cellular proliferation and cytotoxity was determined using MTT assay and Lactate dehydrogenase (LDH)-cytotoxicity assay respectively. Modulation of cytokines (Interleukin (IL)-I Beta, IL-4, IL-5, IL-6, IL-I0, Interferon-gamma, IL-I2, Tumor Necrosis Factor-alpha and Granulocyte macrophage colony-stimulating factor (GM-CSF)) in cervical cells and PBMCs upon stimulation with IncB and IncC was determined by real-time reverse-transcriptase (RT)-PCR and ELISA. Further, CD4 positive $T$ cells were purified from cervical cells and peripheral blood mononuclear cells (PBMCs) and secreted cytokines (Interferon-gamma and IL-4) were evaluated by ELISPOT and real-time RT-PCR.
\end{abstract}

Results: Using MTT assay, significantly high proliferative responses $(P<0.05)$ were observed in inc-stimulated cervical cells and PBMCs from CT-positive fertile women compared to CT-positive women with fertility disorders and controls. Interferon-gamma, IL-12 and GM-CSF were found to be elevated in inc-stimulated cervical cells and PBMCs of CTpositive fertile women compared to CT-positive women with fertility disorders and controls $(P<0.05)$. In contrast, ILI Beta, IL-4, IL-5, IL-6 and IL- I 0 levels were found to be higher in CT-positive women with fertility disorders compared to CT-positive fertile women and controls $(P<0.05)$. Interferon-gamma secreting cells and mRNA expression in incstimulated cervical and peripheral CD4 positive $T$ cells were significantly higher $(P<0.05)$ in $C T$ positive fertile women compared to CT-positive women with fertility disorders.

Conclusion: Our data overall suggests that $\mathrm{CT}$ incs, IncB and IncC modulate host immune responses and may have a role in protection/pathogenesis of genital chlamydial infection in women. 


\section{Background}

Infection with Chlamydia trachomatis (CT), a sexually transmitted pathogen leads to the development of debilitating diseases such as chronic pelvic pain, pelvic inflammatory disease (PID), infertility and ectopic pregnancy in women [1-3]. With approximately 90 million new cases being reported each year, chlamydial infections result in substantial morbidity and socioeconomic burden worldwide $[2,4]$.

Chlamydial infection and propagation within host genital mucosal epithelial cells rely upon a unique biphasic developmental cycle inside a membrane-bound vacuole termed inclusion. The chlamydial life cycle consists of two morphological forms, an extracellular, infectious form the elementary body (EB) which enters host cells and differentiates into an intracellular, metabolically-active reticulate body (RB). Vesicles of the endo- and exocytic pathways and proteins involved in vesicle trafficking are recruited to the inclusion to facilitate effective chlamydial infection in infected cells [5-8]. Chlamydial proteins called inclusion membrane proteins (incs) translocated to the inclusion membrane (IM) by a Type III secretion system are potentially involved in mediating such vesicular trafficking processes $[9,10]$. Host cell components are capable of interacting and modifying segments of incs which are exposed to the cytosolic face of the inclusion $[11,12]$. Further, incs have been reported to generate humoral immunity in infected humans and animals [1317] and cellular immunity by eliciting MHC class Irestricted $\mathrm{CD}^{+} \mathrm{T}$ cell responses [18-20]. Studies on the involvement of CT IncA in homotypic membrane fusion via N-terminal SNARE-like motifs $[8,21]$ and IncA mutant stains have been instrumental in elucidating the role of incs in disease pathogenesis and inducing modified hostcell transcriptional responses [22]. CT IncB and IncC with homologues in C. pneumoniae [23], C. psittaci [16], C. muridarum [24] and C. abortus [25] may be involved in processes like inclusion formation, transportation to perinuclear space and evasion of early lysosomal fusion as their corresponding genes are expressed within 0.5 hours of the infection cycle and coincides with these events.

Emerging evidence on the increasing number of putative incs in all chlamydial genomes [14,23-31] has highlighted the importance of this protein family as probable candidates for intervention of chlamydial disease. Our knowledge on structure and functions of incs has been limited due to the absence of a system for genetically transforming chlamydiae. Alternate strategies like microinjection studies that reported inc phosphorylation by host cell protein phosphokinases $[11,12]$ and yeast two hybrid systems showing IncG interaction with host cell protein (14$3-3 \beta$ ) [12], have put forward the hypothesis that places incs at a central point in the interaction between infected host cells and the chlamydial developmental forms. There is however, no evidence on the role of incs and host immunity in terms of clearance or establishment of infection in the genital tract. We have recently reported seroprevalence of antibodies to chlamydial incs in CT-positive women [32]. Further Inc antibody levels were found to be positively correlated with CT MOMP antibodies and were found to be higher in CT-positive cervicitis patients. These findings brought forward a pondering question- Are chlamydial incs involved in host cell-mediated immune responses and do they have a role to play in pathogenesis of chlamydial infection? This prompted us to further assess cellular immune responses to IncB and IncC in CTinfected women with or without fertility disorders and controls.

In this study gene-specific PCRs were used for detection of $i n c B$ and inc $C$ genes in endocervical samples. Cellular proliferation using MTT assay and cellular damage using LDH assay were assayed in IncB or IncC stimulated cervical cells and peripheral blood mononuclear cells (PBMCs) in enrolled women. Effect of IncB and IncC on cytokine production upon stimulation of cervical cells and PBMC was evaluated by cytokine specific real-time reverse-transcriptase (RT)-PCR assay, ELISA and ELISPOT.

\section{Methods \\ Study population}

After obtaining informed written consent, 296 patients attending the gynaecology outpatient department, Safdarjung Hospital, New Delhi, India were enrolled for the study. Thirty-six healthy age-matched controls attending the family planning department for birth control measures were also enrolled. The study received approval from the hospital's ethics review committee. Procedures followed for sample collection were in accordance with the ethical standards for human experimentation established by the Declaration of Helsinki of 1975 (revised in 1983). At recruitment, a detailed clinical questionnaire was administered to each patient for collecting information on reasons for referral, gynaecology history including menstruation, symptoms of genital and urinary tract infection, obstetric and medical histories. Patients with positive urine pregnancy test, recent antibiotic therapy and with genital tuberculosis were excluded from the study.

Fertile women were those having their last child birth within the last 4 months to 1 year and testing positive for CT during last pregnancy. Women with fertility related disorders included women with infertility and multiple spontaneous abortions. Infertile women were identified as those, which lack recognized conception after 1.5 to 2 years of regular intercourse without the use of contraception. The infertile group included women with referred 
diagnostic laparoscopy [33]. Patients with endometriosis and male factor related infertility were not included in this group. Women with multiple spontaneous abortions (more than 2) were described as those having delivery of pre-viable foetus before the $20^{\text {th }}$ week of gestation.

Since variations in sex hormones are known to influence cytokines concentrations and immune cell population, cervical samples were collected during mid-cycle (median 13 days, range $11^{\text {th }}$ to $15^{\text {th }}$ day of the menstrual cycle). None of the patients had sexual intercourse 3 days or more prior to collection of samples.

\section{Collection of samples}

The vulva was examined for lesions and the cervix for warts, ulcers, ectopy, erythma and discharge, if any. After cleaning the endocervix with a cotton swab (Hi Media, Mumbai, India), endocervical swabs were collected from patients for diagnosis of CT and other STD pathogens. For collection of cervical cells, a cytobrush was placed within the endocervical canal so that the cells from the endocervical region and the zone between the endocervical and ectocervical regions (transformation zone) could be obtained. The cytobrush was then transferred to a sterile centrifuge tube containing sterile phosphate-buffered saline (PBS) ( $\mathrm{pH}$ 7.2) supplemented with 100 U penicil$\mathrm{lin} / \mathrm{ml}, 100 \mu \mathrm{g}$ streptomycin/ml and $100 \mu \mathrm{g}$ glutamine/ ml. No samples were collected from patients with friable cervix and contact bleeding to ensure collection of cervical lymphocytes only. $5 \mathrm{ml}$ of heparinized blood (for isolation of PBMCs) and $2 \mathrm{ml}$ non-heparinized blood (for separating serum) was also collected. Samples were then stored at $4^{\circ} \mathrm{C}$, transported to the laboratory and processed within $1 \mathrm{~h}$.

\section{Laboratory diagnosis}

Endocervical samples were tested for chlamydial positivity by PCR analysis using CT specific 200 base pair (bp) plasmid primers [34]. Diagnosis for other STD pathogens was done as described earlier [33]. In brief, Neisseria gonorrhoeae, Mycoplasma hominis and Ureaplasma urealyticum were detected by culture method along with. In addition Candida sp., bacterial vaginosis and Trichomonas vaginalis were diagnosed by microscopy on gram stained smears.

\section{$C T$ incB and incC $P C R$}

Two sets of primers, set 1 (S1) and set 2(S2) were used for PCR amplification of both CT incB (CT 232) and incC (CT $233)$ genes in all endocervical samples. For PCRs, reaction volumes (total volume $25 \mu \mathrm{l}$ ) contained: $5 \mu \mathrm{l}$ DNA, $2.5 \mu \mathrm{l}$ 10× PCR buffer (200 mM Tris-HCl (pH 8.4), $500 \mathrm{mM}$ $\mathrm{KCl}$ ), $0.5 \mu \mathrm{l} 10 \mathrm{mM}$ dNTP mixture, $0.75 \mu \mathrm{l} 50 \mathrm{mM} \mathrm{MgCl}_{2}$, $3 \mu \mathrm{l}$ of each primer $(5 \mathrm{pM} / \mu \mathrm{l})$, and $0.1 \mu \mathrm{l}$ Taq DNA Polymerase ( $5 \mathrm{U} / \mu \mathrm{l}$, Invitrogen, USA). For incB- and incCS1 primer sets were same as mentioned earlier [35]. PCR reaction tubes were subjected to cycling parameters for incB-S1 amplification at $94^{\circ} \mathrm{C} / 1 \mathrm{~min}, 55^{\circ} \mathrm{C} / 45 \mathrm{sec}, 74^{\circ} \mathrm{C} /$ $1 \mathrm{~min}$ for 34 cycles and incC-S1 amplification atPCR at $94^{\circ} \mathrm{C} / 1 \mathrm{~min}, 54^{\circ} \mathrm{C} / 45 \mathrm{sec}, 74^{\circ} \mathrm{C} / 2$ min for 36 cycles. Further, for this study, unique primer pairs (S2) for both incB and inc $C$ genes were designed using Primer3 software (primer3_www.cgi v 0.1 beta 1a). Primer sequences for incB S2 were: forward primer 5'-GGA TCT ATG GTT CAT TCT GTA TAC AAT TC-3' and reverse primer 5'-GCA TGT CCT ATT CTT GAG GTT TTG TTT G-3'; for incC S2 forward primer 5'-CGG GGT ACC ATG ACG TAC TCT ATA TCC GAT-3' and reverse primer 5'-CCC AAG CTT TTA GCT TAC ATA TAA AGT TTG AG-3'. For S2 primer sets, all reaction tubes were subjected to cycling parameters for incB-S2 amplification at $94^{\circ} \mathrm{C} / 1 \mathrm{~min}, 57^{\circ} \mathrm{C} / 50 \mathrm{sec}, 74^{\circ} \mathrm{C} / 2 \mathrm{~min}$ for 35 cycles and incC-S2 amplification atPCR at $94^{\circ} \mathrm{C} / 1$ $\min , 61^{\circ} \mathrm{C} / 45 \mathrm{sec}, 74^{\circ} \mathrm{C} / 2 \mathrm{~min}$ for 32 cycles.

All primers were commercially synthesized and HPLC purified (MWG-Biotech AG, Ebersberg, Germany). All PCR reactions were performed on DNA Eppendorf Mastercycler personal Thermal Cycler (Eppendorf $\mathrm{GmbH}$, Hamburg, Germany). Amplification products were electrophoresed on $1.2 \%(\mathrm{w} / \mathrm{v})$ agarose gel and ethidium bromide $(0.5 \mathrm{pg} / \mathrm{ml})$ stained gels were visualized on Alpha Imager gel documentation system (AlphaInnotech, San Leandro, USA).

\section{Expression of CT IncB and IncC proteins}

Recombinant clones containing full length gene sequences of incB and inc C cloned into pGEX expression vectors (Amersham Pharmacia Biotech Inc., NJ, USA) were obtained as a kind gift from Dr. Guangming Zhong at Department of Microbiology and Immunology, University of Texas Health Science Center at San Antonio, USA. These clones were further propagated in Terrific Broth (Amresco, Ohio, USA) and production of glutathione Stransferase (GST) fusion proteins was performed as described elsewhere [36]. Briefly, production of GST fusion proteins was induced with isopropyl-D-thiogalactopyranoside (IPTG; Invitrogen, CA, USA) and GST fusion proteins were extracted by lysing the bacteria via sonication in a Triton X-100 lysis buffer (1\% Triton X-100,1 mM phenyl methyl sulfonyl fluoride, $75 \mathrm{U}$ of aprotinin/ml, 20 $\mathrm{M}$ leupeptin, and 1.6 M pepstatin) (Amresco). After a high speed centrifugation to remove debris, the fusion proteincontaining supernatants were further purified with glutathione-conjugated agarose beads (Amersham) according to manufacturer's instructions. The protein concentration was determined with the Bradford assay (Sigma-Aldrich, MO, USA). The non-specific effects of LPS contamination were controlled by treating recombinant proteins with polymyxin B (Sigma-Aldrich). The fusion proteins were checked on sodium dodecyl sulphate (SDS)-polyacrylamide gels stained with a Coomassie blue 
dye (Sigma-Aldrich). Bacterial lysate samples that showed a prominent band at the expected molecular weight position were separated into aliquots and frozen at $-80^{\circ} \mathrm{C}$ to be used in further assays.

\section{Detection of antibodies against $C T$ IncB and IncC}

$\mathrm{CT}$ IncB and IncC specific IgG and IgA titres in cervical washes and sera were determined by ELISA as previously described [37]. Briefly, 96-well plates were coated with 1 $\mu \mathrm{g}$ antigen/well and $100 \mu \mathrm{L}$ of cervical washes or sera from patients were added per well in serial dilutions. Free GST was coated in separate wells to serve as negative controls. After incubation for $2 \mathrm{~h}$ at $37^{\circ} \mathrm{C}$ and subsequent washing with PBS-Tween 20 (PBS-T), plates were incubated with horse radish peroxidase (HRP)- conjugated rabbit antihuman IgG (1:10,000 dilutions) and IgA (1:5000 dilutions) antibodies (Bangalore Genei, Bangalore, India). The binding was measured at $492 \mathrm{~nm}$ in an ELISA reader using OPD (o-phenylenediamine dihydrochloride) as the substrate. Positive samples were defined as those yielding an absorbance (OD) value at least two standard deviations (SDs) above the mean value obtained from the panel of samples taken from the negative subjects.

CT IncB and IncC specific IgG in cervical washes and sera were further determined by Western blot assay. Inc concentrations in bacterial lysate samples were determined by Bradford assay (Bio-Rad Laboratories, CA, USA) with bovine serum albumin as standard. $2 \mu \mathrm{g}$ Incs were electrophoresed on $12 \%$ (SDS)-polyacrylamide gels, transferred to polyvinyl difluoride (PVDF) membrane (Bio-Rad) and reversibly stained with Ponceau S (Sigma-Aldrich) to confirm complete transfer. Membranes were then blocked with 5\% non-fat dry milk in PBS-T and strips of membranes were incubated with individual patients' cervical washes or sera $(1: 100)$. Membranes were further incubated with HRP-conjugated rabbit anti- human IgG (1:1000 dilutions) antibodies and developed by Diaminobenzamide (DAB) (Sigma-Aldrich) as a detection system. Images were analyzed with the help of ImageJ software http://rsb.info.nih.gov/ij/.

\section{Cell cultures}

PBMCs were prepared by Ficoll-Hypaque density gradient centrifugation (Sigma-Aldrich) whereas cervical cells were isolated and counted as described earlier [38]. Cells were then washed three times with Hank's balanced salt solution (Sigma-Aldrich) and suspended in RPMI-1640 medium (Sigma-Aldrich) supplemented with 10\% heatinactivated human $\mathrm{AB}$ serum. Subsequently the cells were then cultured in triplicate $\left(0.6 \times 10^{5}\right.$ cells/well $)$ in roundbottomed 96-well plates with or without stimulants in a total volume of $200 \mu \mathrm{l}$ and were incubated in humidified $5 \% \mathrm{CO}_{2}$ at $37^{\circ} \mathrm{C}$ for $12 \mathrm{~h}$ (for mRNA expression by real- time RT-PCR) and $72 \mathrm{~h}$ (for cell proliferation assays, ELISA and cell proliferation assays).

\section{Stimulants}

Cells were stimulated with/without CT serovar D (a human clinical genital isolate) whole EBs at multiplicity of infection 2 (to serve as CT positive control), IncB $(1 \mu \mathrm{g} /$ $\mathrm{ml})$ and IncC $(1 \mu \mathrm{g} / \mathrm{ml})$. Phytohaemaglutinin (PHA $2 \mu \mathrm{g} /$ $\mathrm{ml}$ ) (Sigma-Aldrich) and free GST were used as positive control mitogen and negative control respectively in each experiment. CT serovar D was grown on confluent McCoy cell monolayers as described previously [39] and EBs were harvested and purified on Renograffin gradients. Optimum concentrations of antigens and mitogen were determined in preliminary experiments as minimum concentrations giving maximal proliferation at different time intervals post stimulation.

\section{Cell proliferation assay}

A colorimetric assay based on MTT (3-(4, 5-dimethylthiazol-2-yl)-2, 5- diphenyl tetrazolium bromide) (SigmaAldrich) was performed to measure the proliferative activity of cervical cells and PBMCs upon stimulation with incs. In brief, at $72 \mathrm{~h}$ post stimulation, $10 \mu \mathrm{l}$ of $5 \mathrm{mg} / \mathrm{ml}$ MTT solution was added to cell cultures, which was incubated for $3 \mathrm{~h}$ at $37^{\circ} \mathrm{C}$. The MTT reaction was terminated by the addition of acidic isopropanol $(40 \mathrm{mM} \mathrm{HCl})$. Absorbance was taken at 570/650 nm using a $\mu$ Quant microplate spectrophotometer (BioTek Instruments, Winooski, VT). The MTT results were expressed as stimulation indices (SI) and an SI value of 2 or more was considered a positive response.

\section{Cell cytotoxity assay}

A colorimetric assay based on measurement of lactate dehydrogenase (LDH) release was performed to measure the cytotoxicity of cervical cells and PBMCs upon stimulation with incs. Release of LDH from damaged cells was measured using LDH-Cytotoxicity Assay Kit (BioVision Research Products, California, USA) according to manufacturer's instructions. Absorbance was taken at 500/600 nm (for LDH) using a $\mu$ Quant microplate spectrophotometer (BioTek Instruments, Winooski, VT). For LDH, positive samples were those yielding an absorbance (OD) value $>$ mean $\pm 2 \mathrm{SD}$ than that of controls.

\section{RNA extraction and real-time RT-PCR analysis for cytokines}

Total RNA from stimulated cervical cells and PBMCs was isolated using RNeasyMini Kit (Qiagen, CA, USA), in accordance with the manufacturer's instructions and stored at $-70^{\circ} \mathrm{C}$. Complementary DNA (cDNA) was prepared using a SuperScript ${ }^{\mathrm{TM}}$ First-Strand Reverse Transcriptase kit (Invitrogen), in accordance with the manufacturer's instructions. The cDNA solution was 
diluted to $150 \mu \mathrm{l}$ and stored at $-20^{\circ} \mathrm{C}$. All samples were reverse transcribed in a single batch and were all analysed for a given primer set in the same PCR run. The PCR amplification employed reagents supplied in a DyNAmo ${ }^{\text {тм }}$ SYBR $^{\circledast}$ Green qPCR Kit (Finnzymes, Espoo, Finland), and each reaction volume $(20 \mu \mathrm{l}$ total $)$ contained $5 \mu \mathrm{l}$ of cDNA, and $0.5 \mu \mathrm{M}$ of both primers. Sequences for endogenous control ( $\beta$-actin) and cytokine genes (IL-1Beta (1 $\beta)$, IL-4, IL-5, IL-6, IL-10, IL-12, Tumor Necrosis Factor-alpha (TNF- $\alpha$ ), Interferon-gamma (IFN- $\gamma$ ) and GM-CSF) used in this study were same as reported earlier by Jasper $e t$ al. [40]. The negative control included in each reaction consisted of $\mathrm{H}_{2} \mathrm{O}$ substituted for cDNA. PCR amplification was performed in an Applied Biosystems 7000 Real-Time PCR System (Applied Biosystems, California, USA) under universal cycling parameters for relative quantification of cytokine expression in target samples according to the manufacturer's instructions (Applied Biosystems User Bulletin \#2: Relative Quantitation of Gene Expression). For data analysis, the $2^{-\Delta \Delta \mathrm{Ct}}$ method was used to calculate fold change [41]. $\beta$-actin expression was used as a reference gene for normalization of threshold cycles $(\mathrm{Ct})$.

\section{Quantification of secreted cytokines}

Quantification of IL-1 $\beta$, IL-4, IL-5, IL-6, IL-10, IL-12, IFN$\gamma$, TNF- $\alpha$ and GM-CSF in culture supernatants of stimulated cervical cells and PBMCs was performed by commercially available ELISA kits (eBiosciences, San Diego, USA), in accordance with the manufacturer's instructions. The absorbance was read at $450 \mathrm{~nm}, \log$-log standard curves were generated and unknowns were interpolated. The minimum detectable cytokine concentrations for these assays were-IL-1 $\beta(4 \mathrm{pg} / \mathrm{ml}), \mathrm{IL}-4(2 \mathrm{pg} / \mathrm{ml}), \mathrm{IL}-5(4 \mathrm{pg} /$ $\mathrm{ml})$, IL-6 (2 pg/ml), IL-10 (2 pg/ml), IL-12 (4 pg/ml), IFN$\gamma(4 \mathrm{pg} / \mathrm{ml})$, TNF- $\alpha(4 \mathrm{pg} / \mathrm{ml})$ and GM-CSF $(2.5 \mathrm{pg} / \mathrm{ml})$.

\section{Antigen specific $C D 4^{+} T$ cell responses}

For purification of $\mathrm{CD} 4^{+} \mathrm{T}$ cells, $\mathrm{CD} 8^{+} \mathrm{T}$ cells were positively selected from cervical cells and PBMCs using CD8 MACS MicroBeads ${ }^{\circledast}$ (Miltenyi Biotec, CA, USA) according to manufacturer's instructions. In brief, $\mathrm{CD} 8^{+}$cells were magnetically labelled with CD8 microbeads and the cell suspension was loaded onto a MACS ${ }^{\varpi}$ column which was then placed in the magnetic field of a MACS separator. The magnetically labelled $\mathrm{CD} 8^{+} \mathrm{T}$ cells were retained in the column while the unlabelled cells which passed through the column were collected; this cell fraction was thus CD8 depleted and contained CD4 ${ }^{+} \mathrm{T}$ cells including antigen presenting cells. This cell fraction was used for further assays and termed as $\mathrm{CD} 4{ }^{+} \mathrm{T}$ cells in the rest of the manuscript. These cells were further gently pelleted and suspended in RPMI-1640 medium (Sigma-Aldrich) supplemented with $10 \%$ heat-inactivated human $\mathrm{AB}$ serum. $\mathrm{CD} 4{ }^{+} \mathrm{T}$ cell cultures $\left(7.5 \times 10^{4}\right.$ cells/well $)$ were then stimulated with IncB or IncC and incubated in humidified 5\%
$\mathrm{CO}_{2}$ at $37^{\circ} \mathrm{C}$ for $12 \mathrm{~h}$ (for RT-PCR) and $18 \mathrm{~h}$ (for ELISPOT). The numbers of IL- 4 and IFN- $\gamma$ producing cells were measured by ELISPOT assay (Diaclone, Cedex, France) as per the manufacturer's instructions and the number of cytokine-secreting cells were counted on a Bioreader ${ }^{\circledast}$ 4000 ELISpot Reader (Biosys, Leeds, UK). To detect transcripts at mRNA levels, real-time RT-PCR analysis of cytokines (IL-4 and IFN- $\gamma$ ) was performed as described above.

\section{Statistical analysis}

The Kruskal-Wallis non parametric test was used to compare continuous variables among multiple groups. The Mann-Whitney U test was used for comparing two groups. Categorical variables were compared using $\chi^{2}$ test. The results were presented with $95 \%$ confidence interval (CI) and $\mathrm{P}<0.05$ was considered significant. All statistical analyses were performed with Graphpad Prism Version 5 (La Jolla, CA, USA).

\section{Results}

\section{Study population}

Cervical CT infection was diagnosed by PCR in 89 patients (Figure 1). Fifteen of these patients were found to be coinfected either with Candida sp., bacterial vaginosis, T. vaginalis, M. hominis, U. urealyticum or $N$. gonorrhoeae in the cervix and were thus excluded from the study. Seven CTpositive patients and two controls were excluded as the count of cervical cells was less than 2 million cells. All healthy controls tested negative for a current CT infection as revealed by absence of CT IgM and IgG antibodies in their sera. Three healthy controls, which were positive for CT IgG antibodies with no current chlamydial infection, were also excluded from the study. Based on clinical history and diagnosis, the patients were categorized into three groups. Group I (GI, $\mathrm{n}=31)$ comprised of CT-uninfected healthy fertile controls, Group II (GII, $\mathrm{n}=38$ ) comprised of fertile CT-positive women and Group III (GIII, $\mathrm{n}$ = 29) comprised of CT-positive women with fertility related disorders. The median ages of women of GI, GII and GIII were comparable $(24,26$ and 27 years, respectively).

\section{Detection of incB and inc $C$ genes}

Detection of incB and incC in endocervical samples was done in 89 patients positive for CT infection. Figure 1 shows representative agarose gels of amplified incB, incC genes in endocervical samples by two sets of primers ( $\mathrm{S} 1$ and S2). Visualization of 357 bp (S1) and 360 bp (S2) amplicons for incB gene and 545 bp (S1) and 554 bp (S2) amplicons for incC gene in $1.2 \%(\mathrm{w} / \mathrm{v})$ agarose gel was considered as positive. All CT-positive patients showed positivity for incB and incC genes. 

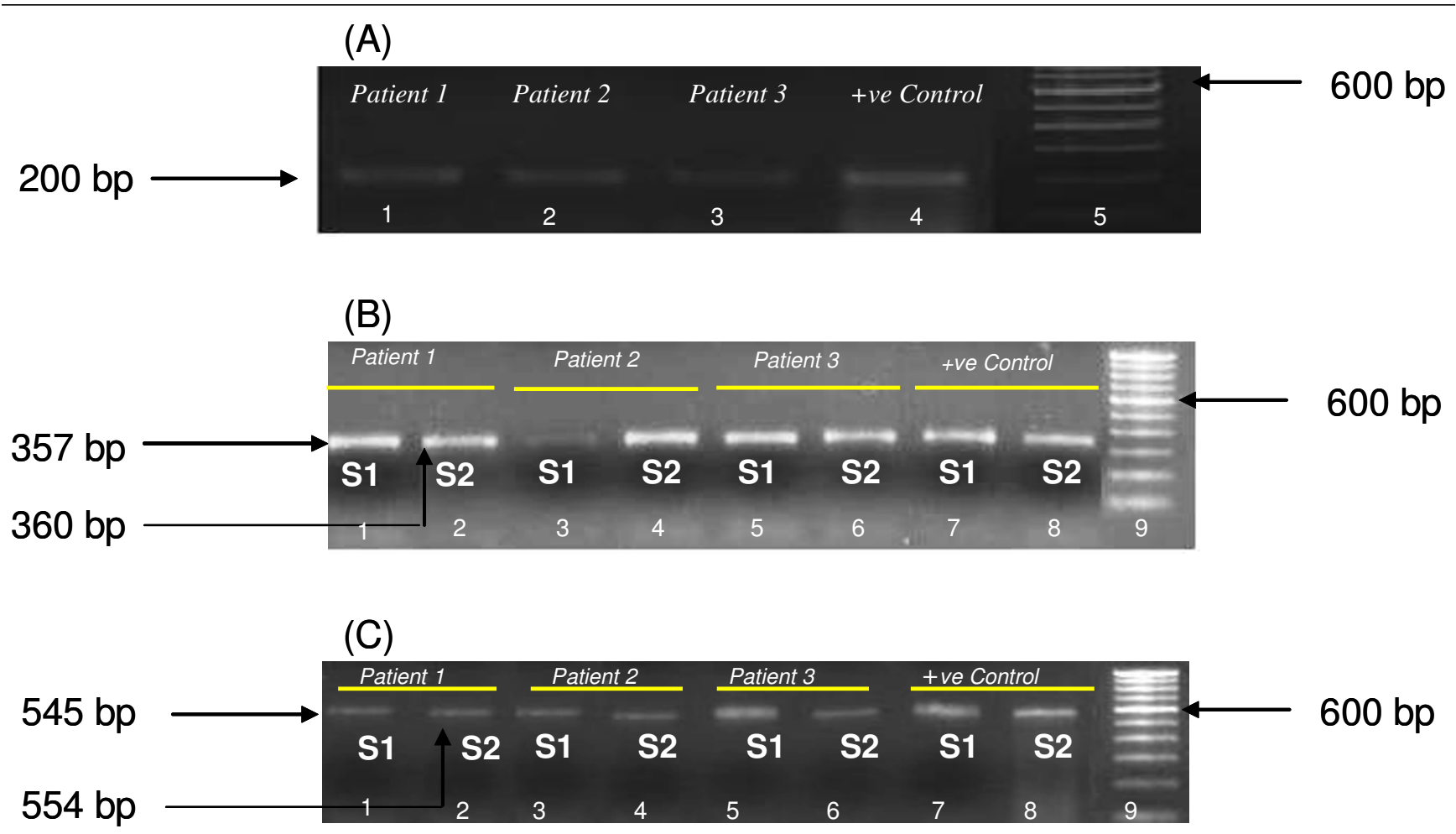

Figure I

PCR detection of incB and inc $C$ genes in endocervical samples of CT-positive patients. (A) Gel showing 200 bp amplicons of CT plasmid. Lanes I, 2, 3 - PCR positivity in patients I, 2, 3 respectively; lane 4- positive control; lane 5- I00 bP Ladder (Invitrogen). (B) Agarose gel showing PCR positivity for CT-incB gene. Lanes I, 3, 5- incB SI PCR amplicons in patients I, 2, 3 respectively; lane 7-positive control; lanes 2, 4, 6 - incB S2 PCR amplicons in patients I, 2, 3 respectively; lane 8-positive control; lane 9 is 100 bp Ladder (Invitrogen). (C) Agarose gel showing PCR positivity for CT-incC gene. Lanes I, 3, 5-incC SI PCR amplicons in patients I, 2, 3 respectively; lane 7-positive control; lanes 2, 4, 6 - incC S2 PCR amplicons in patients I, 2, 3 respectively; lane 8-positive control; lane 9 is 100 bp Ladder (Invitrogen).

Table I: Prevalence of IncB and IncC specific antibodies in study population

\begin{tabular}{|c|c|c|c|c|c|c|c|c|c|}
\hline \multirow[t]{2}{*}{ Groups } & \multirow{2}{*}{$\begin{array}{c}\text { Age } \\
\text { Median } \\
\text { (Range) }\end{array}$} & \multicolumn{2}{|c|}{ IncB IgG've } & \multicolumn{2}{|c|}{$\operatorname{lnc} B \lg A^{+v e}$} & \multicolumn{2}{|c|}{ IncC IgG ${ }^{+v e}$} & \multicolumn{2}{|c|}{ IncC IgA $A^{\text {tve }}$} \\
\hline & & Serum & $\begin{array}{l}\text { Cervical } \\
\text { Washes }\end{array}$ & Serum & $\begin{array}{l}\text { Cervical } \\
\text { Washes } \\
\text { n (\%) }\end{array}$ & Serum & $\begin{array}{l}\text { Cervical } \\
\text { Washes }\end{array}$ & Serum & $\begin{array}{l}\text { Cervical } \\
\text { Washes }\end{array}$ \\
\hline $\begin{array}{l}\text { Group I } \\
(n=3 I)\end{array}$ & $24(2 I-28)$ & $2(6)$ & $I(3)$ & $I(3)$ & $I(3)$ & $2(6)$ & $\mathrm{I}(3)$ & $\mathrm{I}(3)$ & $I(3)$ \\
\hline $\begin{array}{l}\text { Group II } \\
(n=38)\end{array}$ & $26(22-29)$ & $36(95)^{\mathrm{a}}$ & $24(63)^{b}$ & $23(61)^{c}$ & $29(77)^{d}$ & $34(89)^{e}$ & $27(7 I)^{f}$ & $26(68)^{g}$ & $32(84)^{\mathrm{h}}$ \\
\hline $\begin{array}{l}\text { Group III } \\
(n=29)\end{array}$ & $27(22-31)$ & $27(93)^{i}$ & $\mathrm{II}(38)^{\mathrm{i}}$ & $17(59)^{k}$ & $15(52)^{\mid}$ & $26(90)^{\mathrm{m}}$ & $13(45)^{n}$ & $28(96)^{\circ}$ & I7(59)P \\
\hline
\end{tabular}

Note values in parenthesis represent corresponding percentages unless otherwise stated.

a $P=N S$ as compared to GIII; ${ }^{b} P=0.0428$ as compared to GIII; ${ }^{c} P=N S$ as compared to GIII; $P=0.0378$ as compared to GIII; e $P=N S$ as

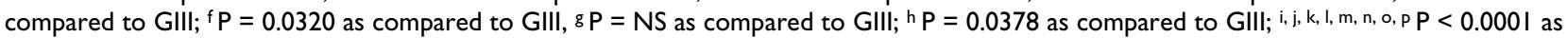
compared to corresponding GI where, Group I (GI) comprised of healthy fertile women with no CT infection, Group II (GII) comprised of CTpositive fertile women, Group III (GIII) comprised of CT-positive women with fertility disorders.

IncB- CT Inclusion membrane protein B; IncC- CT Inclusion membrane protein C; CT- Chlamydia trachomatis; IgG- Immunoglobulin G; IgAImmunoglobulin $A ;$ +ve- positive. All categorical variables were compared using the $\chi^{2}$ test. 


\section{Detection of antibodies against IncB and IncC by ELISA} IgG and IgA antibodies to both IncB and IncC were detected significantly high $(\mathrm{P}<0 \cdot 05)$ in cervical washes of CT-positive patients with or without fertility disorders compared to controls. However, there was no significant difference $(\mathrm{P}>0.05)$ between IgG and IgA antibodies to both IncB and IncC in sera obtained from CT-positive women with or without fertility disorders (Table 1). Further, significant correlation was observed between antibodies to incs in cervical washes and sera in CT-positive women with or without fertility related disorders (Table 2).

Presence of IncB and IncC antibodies in cervical washes and sera was further confirmed by Western blot assay (Figure 2). Western blot assay showed presence of a $38 \mathrm{kDa}$ band for IncB and a $44.4 \mathrm{kDa}$ band for IncC in CT-positive samples. No corresponding bands were observed in cervical washes and sera obtained from controls.

\section{Cell proliferation}

MTT assay was used to evaluate cellular proliferation of cervical cells and PBMCs upon stimulation with IncB and IncC. Proliferative responses ( $\mathrm{SI}>2$ ) to IncB and IncC was statistically significant $(\mathrm{P}<0 \cdot 05)$ in cervical cells (Figure 3A) and PBMCs (Figure 3B) from CT-positive fertile women compared to CT-positive women with fertility disorders or controls. Stimulation with free GST (which served as negative controls) showed no significant differences in proliferative responses in any group (data not shown).

\section{Cell cytotoxity assays}

Damage to plasma membranes of cells stimulated with incs was evaluated by measuring the release of $\mathrm{LDH}$, a stable cytoplasmic enzyme into culture supernatants. No significant difference $(\mathrm{P}>0.05)$ was observed in the number of positive responders for LDH release in cervical cells and PBMCs isolated from CT-positive patients and controls (Table 3). Free GST did not produce significant differences in LDH in any group (data not shown).

\section{Cytokine mRNA expression levels in inc-stimulated cervical cells and PBMCs}

Messenger RNA for IL-1 $\beta$, IL-4, IL-5, IL-6, IL-10, IL-12, TNF- $\alpha$, IFN- $\gamma$ and GMCSF was detected in stimulated cervical cells and PBMCs in all patients' groups. On stimulation of cervical cells (Figure 4) and PBMCs (Figure 5) with incs, significant increase in mRNA expression levels of IFN- $\gamma$, IL-12, and GM-CSF $(\mathrm{P}<0.05)$ was observed in cervical cells and PBMCs obtained from CT-positive fertile women compared to other groups. In contrast, IL-1 $\beta$, IL4, IL-5, IL-6 and IL-10 mRNA expression levels were significantly higher $(\mathrm{P}<0.05)$ in cells obtained from CT-positive women with fertility disorders compared to other two groups. There were no changes in cytokine mRNA expression in cervical cells and PBMCs stimulated with free GST (data not shown).

\section{ELISA for cytokines in cell supernatants of inc-stimulated cervical cells and PBMCs}

Significantly higher levels of IL-1 $\beta$, IL- 6 and IL-10 were detected upon inc-stimulation of cervical cells (Table 4) and PBMCs (Table 5) from CT-positive women with fertility disorders as compared to CT-positive fertile women or controls $(\mathrm{P}<0.05)$. In contrast, cervical cells and PBMCs obtained from CT-positive fertile women secreted significantly higher levels of IL-12, IFN- $\gamma$ and GM-CSF compared to CT-positive women with fertility disorders or controls $(\mathrm{P}<0.05)$. Significantly high levels of TNF- $\alpha$ and IL-6 levels were secreted in cervical cells and PBMCs from CT-positive fertile women compared to controls. IL-4 and IL-5 was below detection limit in all culture supernatants (data not shown). Cervical cells and PBMCs cultures stimulated with free GST showed no significant differences in levels of secreted cytokines (data not shown).

\section{Antigen specific $C D 4^{+} \mathrm{T}$ cell responses}

IL-4 and IFN- $\gamma$ spot forming cells (SFCs) were enumerated in inc-stimulated CD4 $4^{+} \mathrm{T}$ cells purified from cervical cells and PBMCs in CT-positive women with and without fertility disorders and controls. As shown in Table 6, CD4+ T cells in CT-positive fertile women exhibited significantly elevated numbers of IFN- $\gamma$ SFCs, in a dose-dependent

Table 2: Correlation of IncB and IncC specific antibodies in study population

\begin{tabular}{lll}
\hline Antibodies & GII & GIII \\
& r(P) & (P) \\
\hline IncB IgG and IncC IgG in sera & $0.47(0.0047)$ & $0.54(0.0148)$ \\
IncB IgG and IncC IgG in cervical washes & $0.57(0.0040)$ & $0.94(<0.0001)$ \\
IncB IgA and IncC IgA in sera & $0.56(0.0049)$ & $0.92(0.0003)$ \\
IncB IgA and IncC IgA in cervical washes & $0.43(0.0172)$ & $0.60(0.018)$ \\
\hline
\end{tabular}

Note. Correlation was tested with Spearman's correlation coefficient $(r)$. Values in parenthesis represent corresponding significant levels unless otherwise stated.

$n$ - number of patients, $r$ - Spearman's correlation coefficient.

Significant correlations was observed in GII and GIII where, Group II (GII) comprised of CT-positive fertile women, Group III (GIII) comprised of

CT-positive women with fertility disorders. 
(A)

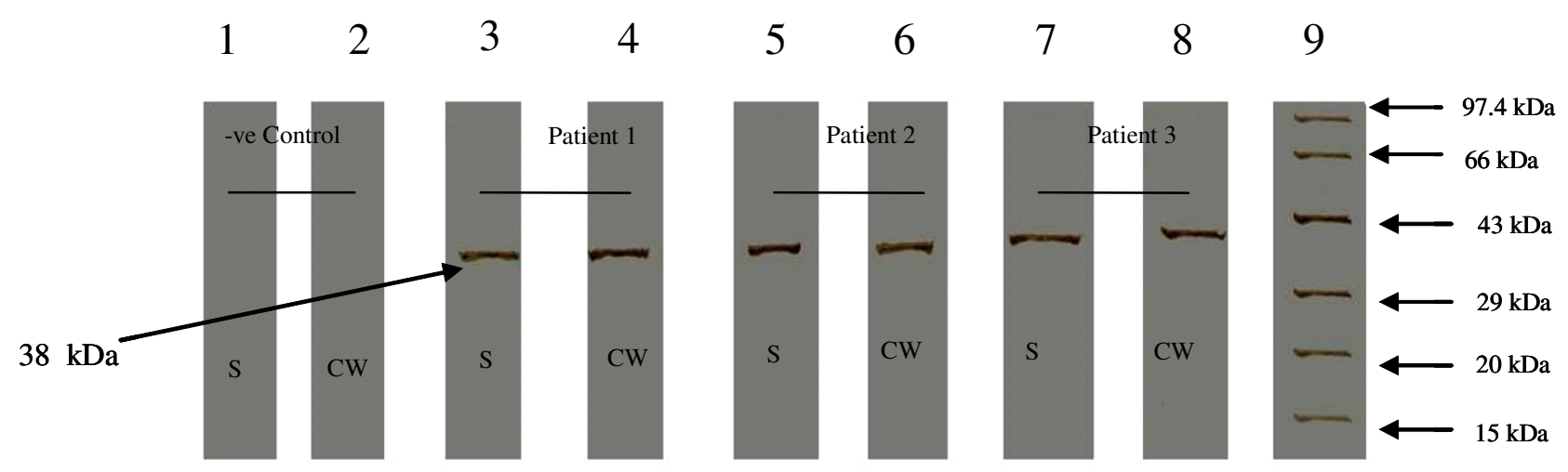

(B)
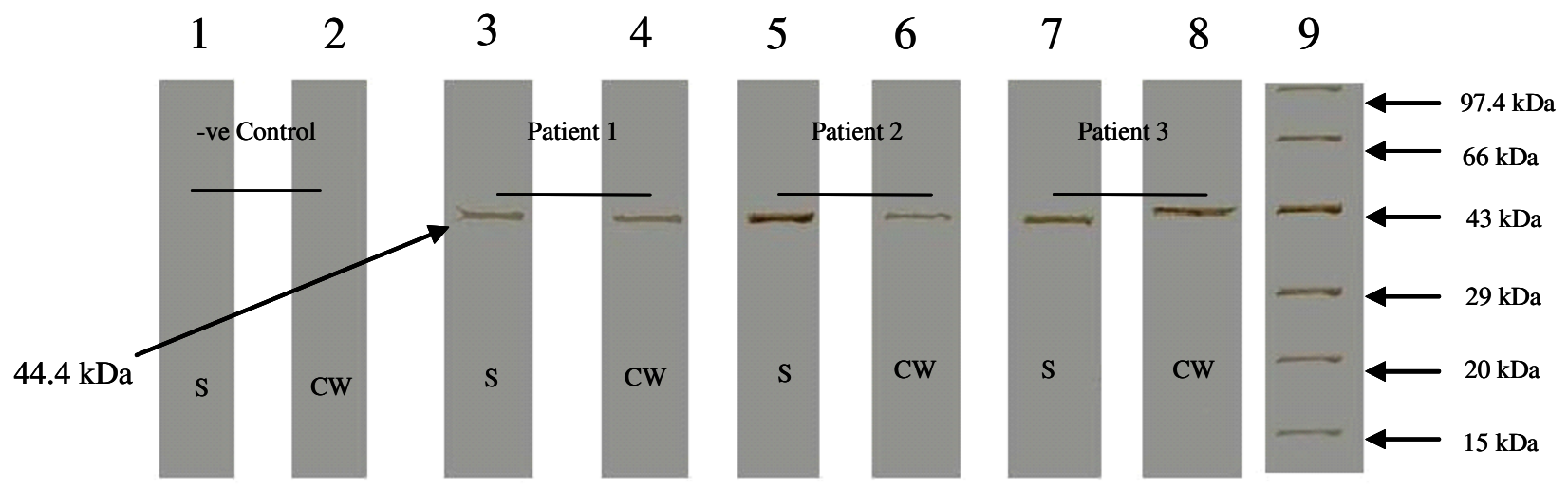

Figure 2

Western blot assay for detection of anti-IncB and anti-IncC IgG antibodies. Detection of (A) anti-IncB IgG and (B) anti-IncC IgG antibodies in sera (S) and cervical washes (CW) obtained from CT-positive patients and controls. Strips 3, 5, 7Detection of IncB IgG antibodies in sera (S) of patients' I, 2, 3 respectively; strips 2, 4, 6- Detection of IncB IgG antibodies in cervical washes (CW) of patients' I, 2, 3 respectively; strips I, 2 - Serum and cervical wash respectively obtained from CT-negative patient (which served as negative controls for assay). Strip 9 - Molecular weight marker (Bangalore Genei). A 38 kDa band (IncB specific $\operatorname{lgG}$ ) and $44.4 \mathrm{kDa}$ band (IncC specific $\operatorname{lgG}$ ) was detected in sera and cervical washes obtained from CT-positive patients. No bands were observed in negative control. IncB- CT Inclusion membrane protein B; IncC- CT Inclusion membrane protein C; CT- Chlamydia trachomatis; kDa- Kilodaltons; S- Serum; CW- Cervical washes.

fashion, upon stimulation with $0.5 \mu \mathrm{g} / \mathrm{ml}$ or $1 \mu \mathrm{g} / \mathrm{ml}$ of both IncB and IncC, as compared to cells from CT-positive women with fertility disorders. Cells stimulated with EBs (positive control) showed maximal IFN- $\gamma$ SFCs whereas cells stimulated with free GST (negative control) showed negligible IFN- $\gamma$ production (data not shown). Further, frequency of IFN- $\gamma$ secreting cells was highest among CD4 ${ }^{+} \mathrm{T}$ cells in cervical cells and PBMCs obtained from CT-positive fertile women followed by controls. In CTpositive women with fertility disorders, significantly $(\mathrm{P}<$
$0.05)$ lower number of IFN- $\gamma$ SFCs was present. There was no detectable IL-4 SFCs in any of the cell cultures (data not shown).

Real time RT-PCR analysis showed significant $(\mathrm{P}<0.05)$ increase in IFN- $\gamma$ mRNA in purified CD4+T cells obtained from cervical cells and PBMCs in CT-positive fertile women compared to CT-positive women with fertility disorders (Figure 6). Relative expression of IFN- $\gamma$ was higher in CT-positive fertile women and controls with respect to 
(A)

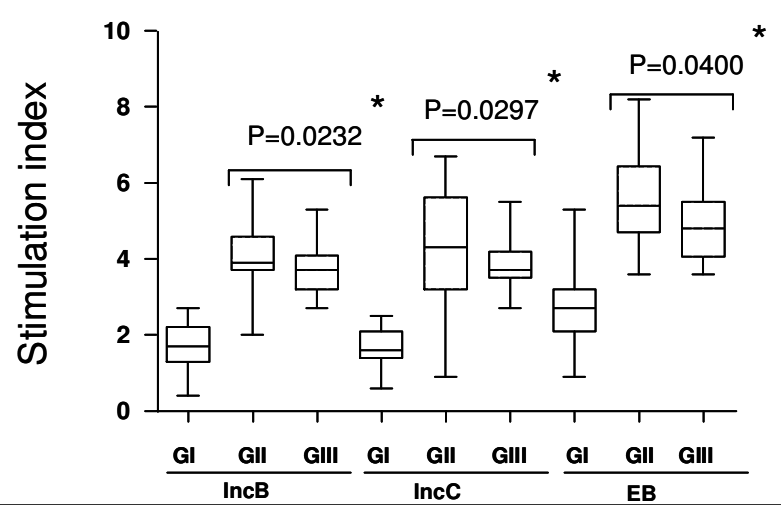

(B)

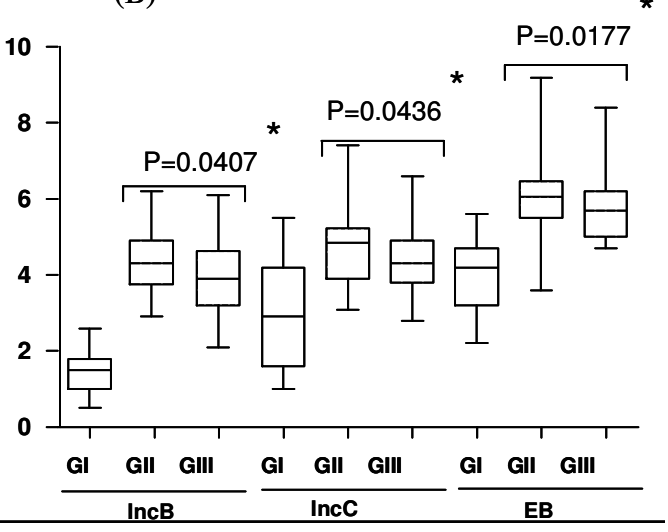

Figure 3

MTT assay showing proliferative responses. Proliferative responses (stimulation indices) of $(A)$ cervical cells and $(B)$ PBMCs isolated from GI, GII, GIII on stimulation with IncB, IncC and CT EB were estimated by MTT assay. (A) *Significant difference in proliferative responses in GII with respect to GIII $(P=0.0232, P=0.0297$ and $P=0.0400$ upon stimulation with IncB, Inc $C$ and $E B$ respectively). (B) *Significant difference in proliferative responses in Gll with respect to GIII $(P=0.0407, P=$ 0.0436 and $P=0.0 I 77$ upon stimulation with $I n c B$, IncC and CT EBs respectively) where; Group I (GI) comprised of healthy fertile women with no CT infection, Group II (GII) comprised of CT-positive fertile women, Group III (GIII) comprised of CTpositive women with fertility disorders. The horizontal line in the middle of the box is the median value of the responses and the lower (upper) is the 25th (75th) percentile., *Significant; PBMCs- Peripheral blood mononuclear cells; IncB- CT Inclusion membrane protein B; IncC- CT Inclusion membrane protein C; CT- Chlamydia trachomatis; EB- Elementary Bodies; n- Number. Proliferative responses between groups were evaluated using Mann-Whitney $U$ test.

CT-positive women with fertility disorders. Expression of IL-4 was low and not significant in CT-positive women and controls (data not shown).

\section{Discussion}

To the best of our knowledge, this is the first study on mucosal and peripheral immune responses to chlamydial inclusion proteins in CT-positive women with or without fertility disorders. Although several inc proteins have been identified in different chlamydial species however, their role in chlamydial biology, especially with respect to gen- erating host immune responses in not clear. Being present at the cytoplasmic face of the inclusion, incs are critical for direct interactions with proteins in the host cell cytosol $[11,12,42,43]$.

Using reported [35], and unique primer sets, we were able to detect incB and incC genes in CT-positive endocervical samples. The prevalence of antibodies against IncB and IncC in cervical washes was detected significantly high in CT-positive fertile women compared to CT-positive women with fertility disorders showing their involvement

Table 3: Lactate dehydrogenase (LDH) assay for cell cytotoxicity

\begin{tabular}{|c|c|c|c|c|c|c|}
\hline \multirow[b]{3}{*}{ Groups } & \multicolumn{6}{|c|}{ No. of patients' positive for LDH release from cells stimulated with chlamydial antigens } \\
\hline & \multirow[b]{2}{*}{ IncB } & \multicolumn{2}{|c|}{ Cervical cells } & \multicolumn{2}{|c|}{ PBMCs } & \multirow[b]{2}{*}{ EBs } \\
\hline & & IncC & EBs & $\begin{array}{l}\text { IncB } \\
(\%)\end{array}$ & IncC & \\
\hline GI & $2(6.45)$ & $3(9.67)$ & $2(6.45)$ & $2(6.45)$ & $2(6.45)$ & $2(6.45)$ \\
\hline GII & $3(7.89)^{\mathrm{a}}$ & $4(10.52)^{b}$ & $3(7.89)^{c}$ & $2(5.26)^{d}$ & $4(10.52)^{e}$ & $5(13.15)^{f}$ \\
\hline GIII & $4(13.79)$ & $3(10.34)$ & $5(17.24)$ & $4(13.79)$ & $4(13.79)$ & $3(10.34)$ \\
\hline
\end{tabular}

Note. Table shows the number of patients $(n)$ positive for LDH release in culture supernatants of stimulated cells. Cervical cells and PBMCs were isolated from patients of GI, GII and GIII and stimulated with chlamydial antigens IncB, IncC and EBs. The number of patients positive for LDH release into culture supernatants post stimulation was noted. Values in parentheses represent corresponding percentages.

a, b, c, d, e, f P not significant as compared to corresponding GI and GIII where, Group I (GI) comprised of healthy fertile women with no CT infection, Group II (GII) comprised of CT-positive fertile women, Group III (GIII) comprised of CT-positive women with fertility disorders.

LDH- Lactate dehydrogenase; PBMCs-Peripheral blood mononuclear cells; IncB- CT Inclusion membrane protein B; IncC- CT Inclusion membrane protein C; CT- Chlamydia trachomatis; EBs-Elementary bodies.

All categorical variables were compared using the $\chi^{2}$ test. 


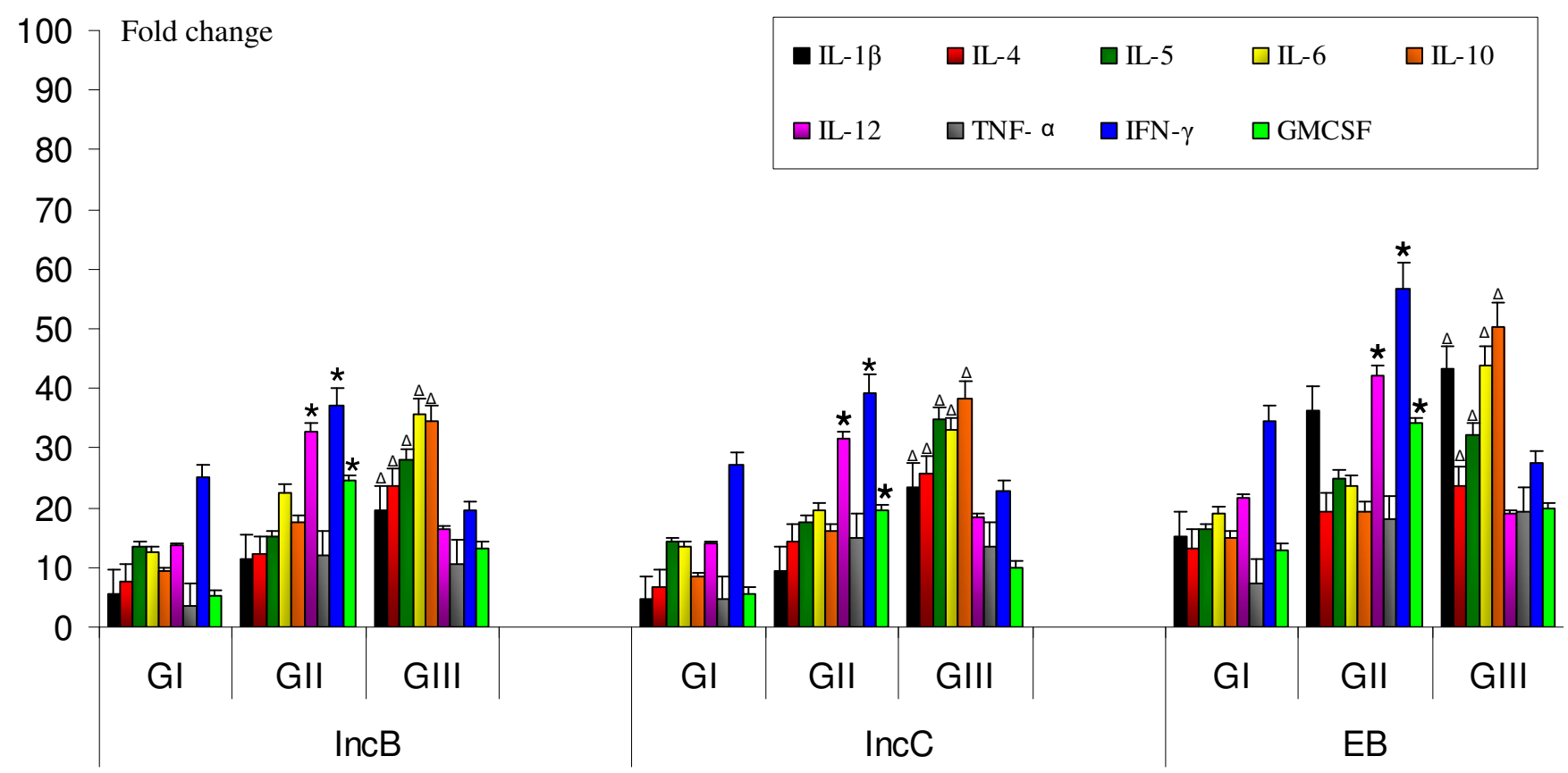

Figure 4

Cytokine mRNA expression in inc-stimulated cervical cells. Estimation of mRNA expression of IL- I $\beta$, IL-4, IL-5, IL-6, IL-I0, IL-12, TNF- $\alpha$, IFN- $\gamma$ and GMCSF in $0.6 \times 10^{5}$ cervical cells after in vitro stimulation with IncB, IncC and CT EB. Real-time RT-PCR analysis of mRNA levels was done at 12 hours post infection in cervical cells isolated from GI, GII and GIII where, Group I (GI) comprised of healthy fertile women with no CT infection, Group II (GII) comprised of CT-positive fertile women, Group III (GIII) comprised of CT-positive women with fertility disorders. * P 0.05 Expression of cytokine mRNA in GII compared to corresponding levels in GI and GIII by Kruskal Wallis test. $\Delta \mathrm{P}<0.05$ Expression of cytokine mRNA in GIII compared to corresponding levels in GI and GIl by Kruskal Wallis test. RT-PCR- Reverse-Transcriptase PCR; IncB- CT Inclusion membrane protein B; IncC- CT Inclusion membrane protein C; CT-Chlamydia trachomatis; EB-Elementary bodies; IL-Interleukin; $\beta$ Beta; IFN- $\gamma$-Interferon gamma; TNF- $\alpha$-Tumor Necrosis factor alpha; GMCSF- Granulocyte macrophage colony-stimulating factor. All cytokines were normalised against corresponding levels of $\beta$-actin endogenous gene. The graph show results as fold change represented by bars. Bars represent mean \pm s.e.m. for all experiments. $X$ axis- Stimulants used in the study; $Y$-axis- Fold change in RNA expression under different conditions.

in initial infection than in established disease pathology. However, antibodies to IncB and IncC were not significantly different in sera in the same patients' groups. The differential immunogenic properties of inclusion proteins and their involvement in particular disease pathologies may be attributed to the native conformational structures of proteins in vivo and their cellular localization. Further, new information on the 3 dimensional structures of IncB and IncC is required which will be helpful in understanding arrangement of epitopes necessary for generating antibodies against these proteins within infected host cells. High prevalence of antibodies against CT MOMP antigen in patients with primary chlamydial infections has also been reported [38]. In addition to their roles in neutralizing infectious organisms, antibodies to CT surface elements are known to dramatically enhance opsonization of dendritic cells and to promote strong Th1 immune responses [44]. Conversely, antibodies against cHSP60 antigen in patients with recurrent infections [38] and against recombinant cHSP60 proteins in women with fertility disorders have also been reported [45]. Serological data have shown a strong association between antibody responses to CHSP60 and sequalae of CT infection, including PID, tubal infertility, ectopic pregnancy, and scarring trachoma [46-50].

Cellular proliferation in cervical cells and PBMCs using MTT assay showed higher stimulation indices for IncB or IncC in CT-positive fertile women as compared to controls and CT-positive women with fertility disorders. Previous studies on lymphocyte proliferation to chlamydial antigens, including MOMP and heat shock protein 60 , have shown enhanced responses in individuals who spontaneously resolve trachoma infection as compared to those with persistent infections [51]. In another study relative depression in lymphocyte proliferation in response to CT antigens in subjects with persistent clinical signs of inflammatory trachoma and in subjects with severe tra- 


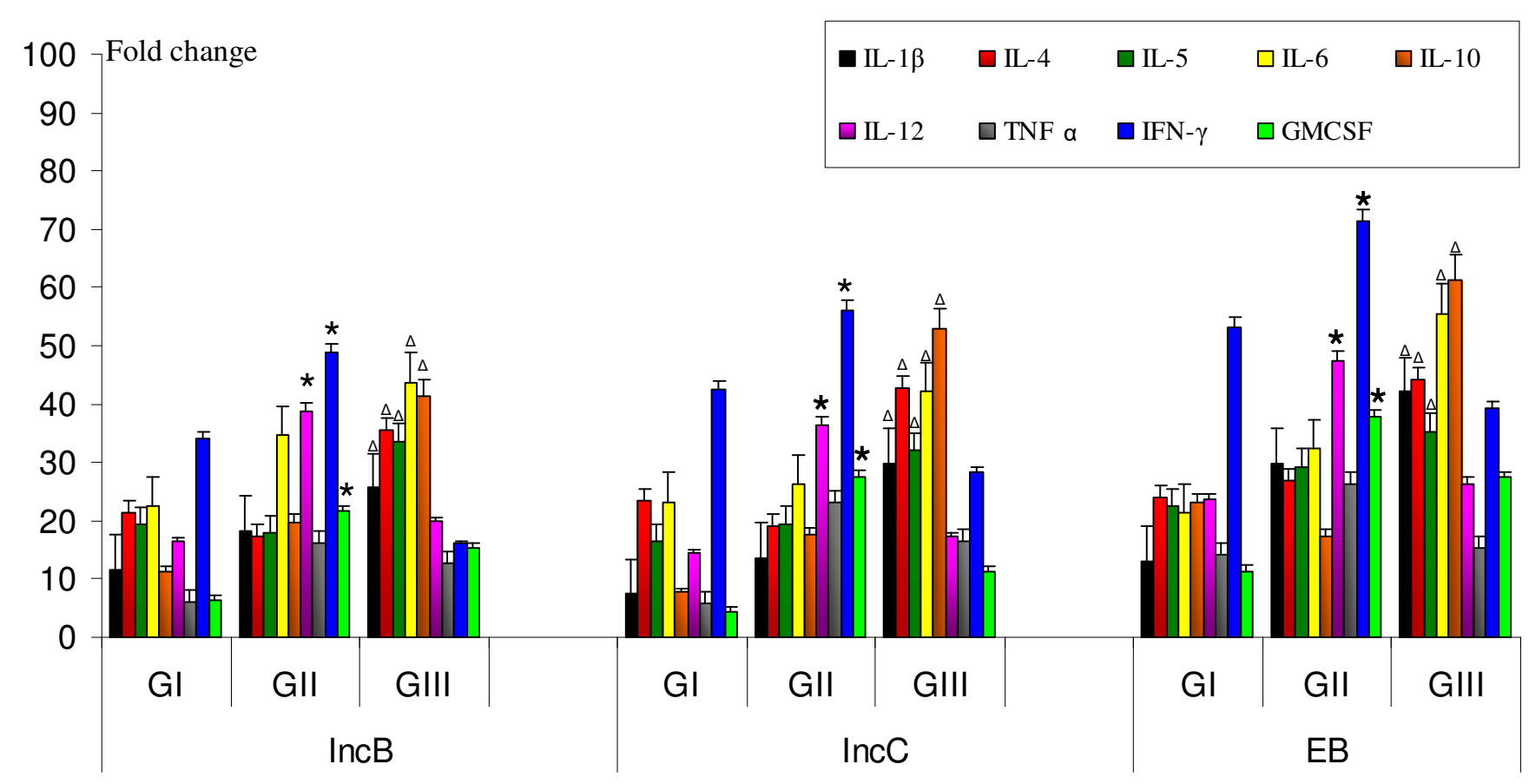

Figure 5

Cytokine mRNA expression in inc-stimulated PBMCs. Estimation of mRNA expression of IL-I $\beta$, IL-4, IL-5, IL-6, IL-I0, IL-I 2, TNF- $\alpha$, IFN- $\gamma$ and GMCSF in $0.6 \times 10^{5}$ PBMCs after in vitro stimulation with IncB, IncC and CT EB. Real-time RT-PCR analysis of mRNA levels was done at 12 hours post infection in PBMCs isolated from GI, Gll and GIII where, Group I (GI) comprised of healthy fertile women with no CT infection, Group II (GII) comprised of CT-positive fertile women, Group III (GIII) comprised of CT-positive women with fertility disorders. * $\mathrm{P}<0.05$ Expression of cytokine mRNA in GII compared to corresponding levels in GI and GIII by Kruskal Wallis test. $\Delta \mathrm{P}<0.05$ Expression of cytokine mRNA in GIII compared to corresponding levels in GI and GIl by Kruskal Wallis test. RT-PCR- Reverse-Transcriptase PCR; IncB- CT Inclusion membrane protein B; IncC- CT Inclusion membrane protein C; CT- Chlamydia trachomatis; EB-Elementary bodies; IL-Interleukin; $\beta$-Beta; IFN- $\gamma$-Interferon gamma; TNF- $\alpha$-Tumor Necrosis factor alpha; GMCSF- Granulocyte macrophage colony-stimulating factor. All cytokines were normalised against corresponding levels of $\beta$-actin endogenous gene. The graph show results as fold change represented by bars. Bars represent mean \pm s.e.m. for all experiments. $X$ axis- Stimulants used in the study; $Y$-axis- Fold change in RNA expression under different conditions.

chomatous scarring has been reported too [52]. CT IncC has been reported to have insignificant effect on altering host cell cytokinesis whereas CT 223-227 caused maximum reduction in host cell cytokinesis and facilitated centromere supranumeracy defects in transfected HeLa or McCoy cells [53]. Further our data on the number of positive responders for LDH release showed no significant differences between CT-positive patients and controls. Thus both incs failed to cause any disruption of cellular integrity of stimulated cervical cells and PBMCs thereby suggesting that these incs could initiate specific cellular immune responses.

Results in this study suggest that exposure to incs could significantly affect host immune function by modifying the release of cytokines. On comparing cytokine expression by cells obtained from CT-positive fertile women with those with controls and CT-positive women with fertility disorders, cells from CT-positive women with fertil- ity disorders secreted significantly higher levels of IL-1 $\beta$. The probable role of IL-1 in fallopian tube destruction during CT infection has been reported [54]. Further, it is also shown that synovial tissues from chronic arthritis patients with synovial C. pneumoniae infection have significant levels of mRNA for IL-1 $\beta$ [55]. These results collectively confirm that IL-1 $\beta$ can be one of the cytokines that are responsible for chlamydial pathology.

Both incs induced high levels of IL-6 in cells from CT-positive fertile women with or without fertility disorders in comparison to controls. In CT-infected cells, IL- 6 has been reported to act synergistically with IL-12, for inducing protective immune responses [56]. However, our data showed that highest IL- 6 levels were produced in inc-stimulated cells from CT-positive patients with fertility disorders suggesting the pathogenic role of IL- 6 . High levels of IL-6 levels have been previously reported to be present in the tubal fluids of patients with infertility caused by 
Table 4: Cytokine concentrations in culture supernatants of stimulated cervical cells

\begin{tabular}{|c|c|c|c|c|c|c|c|c|c|}
\hline & \multicolumn{3}{|c|}{ GI } & \multicolumn{3}{|c|}{ GII } & \multicolumn{3}{|c|}{ GIII } \\
\hline & IncB & IncC & EBs & IncB & IncC & EBs & IncB & IncC & EBs \\
\hline IL-I $\beta$ & $\begin{array}{c}\mathbf{7 8} \\
(49.5-235.9)\end{array}$ & $\begin{array}{c}93 \\
(58.6-286.9)\end{array}$ & $\begin{array}{c}\text { I43.6 } \\
(52.1- \\
362.76)\end{array}$ & $\begin{array}{c}143 \\
(61.8-38 \mid .5)\end{array}$ & $\begin{array}{c}167.2 \\
(55.2-4 \mid 7.3)\end{array}$ & $\begin{array}{c}268 \\
(48.6-473.6)\end{array}$ & $\begin{array}{c}293.2^{\mathrm{a}} \\
(77.5-731.4)\end{array}$ & $\begin{array}{c}327.5^{\mathrm{b}} \\
(65.3-821.8)\end{array}$ & $\begin{array}{c}521 . I^{c} \\
(86.2-921.1)\end{array}$ \\
\hline IL-6 & $\begin{array}{c}\text { II I } \\
(38.2-37 \mid .5)\end{array}$ & $\begin{array}{c}127.4 \\
(52.1-443.4)\end{array}$ & $\begin{array}{c}178.65 \\
(67.9- \\
871.76)\end{array}$ & $\begin{array}{c}398.4^{d} \\
(82.8-671.8)\end{array}$ & $\begin{array}{c}431.56 \mathrm{e} \\
(97.6-544.9)\end{array}$ & $\begin{array}{c}63 I^{f} \\
(111.7- \\
931.6)\end{array}$ & $\begin{array}{c}732.3^{a} \\
(241.3- \\
\mid 121.62)\end{array}$ & $\begin{array}{c}756.6 \mathrm{I}^{\mathrm{b}} \\
(222.9- \\
1006.8)\end{array}$ & $\begin{array}{l}\text { I I 07. Ic } \\
(34 \mid- \\
\mid 621.8)\end{array}$ \\
\hline IL-IO & $\begin{array}{c}158.6 \\
(100.1- \\
267.2)\end{array}$ & $\begin{array}{c}172.2 \\
(97.6-342.5)\end{array}$ & $\begin{array}{c}183.4 \\
(92.6- \\
512.46)\end{array}$ & $\begin{array}{c}366.9 \\
(112.5- \\
548.9)\end{array}$ & $\begin{array}{c}387.9 \\
(126.1- \\
561.9)\end{array}$ & $\begin{array}{c}537.8 \\
(22|-7| 2.5)\end{array}$ & $\begin{array}{c}956.9 a \\
(347.9- \\
1231)\end{array}$ & $\begin{array}{l}\mathbf{8 6 9 . 7 b} \\
(358.7- \\
1331.9)\end{array}$ & $\begin{array}{l}\text { I 259.8c } \\
(568.7- \\
|7| 2.89)\end{array}$ \\
\hline IL-I 2 & $\begin{array}{c}152.5 \\
(97.4-306.8)\end{array}$ & $\begin{array}{c}168.9 \\
(88.8-277.1)\end{array}$ & $\begin{array}{c}251.8 \\
(113.7- \\
342.7)\end{array}$ & $\begin{array}{c}289.8 \mathrm{~g} \\
(134.6-450)\end{array}$ & $\begin{array}{c}2^{297.6^{h}} \\
(156.9- \\
430.7)\end{array}$ & $\begin{array}{c}\mathbf{5 6 6 . 5} \mathbf{i} \\
(189.4- \\
821.6)\end{array}$ & $\begin{array}{c}141.4 \\
(68.9-28 \mid .8)\end{array}$ & $\begin{array}{c}156.8 \\
(75.8-3 \mid 2.8)\end{array}$ & $\begin{array}{c}171.6 \\
(126.9-400)\end{array}$ \\
\hline IFN- $\gamma$ & $\begin{array}{c}3 \mathbf{I} \mathbf{2 . 5 \mathbf { j }} \\
(78.8-454.3)\end{array}$ & $\begin{array}{c}321.8^{k} \\
(91.3-431.6)\end{array}$ & $\begin{array}{c}426.71 \\
(122.6- \\
600.1)\end{array}$ & $\begin{array}{c}512.5 \mathrm{~g} \\
(346.1- \\
861.4)\end{array}$ & $\begin{array}{c}571.3^{\mathrm{h}} \\
(311.9- \\
814.3)\end{array}$ & $\begin{array}{l}\mathbf{8 4 3 . 8} \mathbf{i} \\
(424.8- \\
\text { |272.5) }\end{array}$ & $\begin{array}{c}168.2 \\
(107.9- \\
575.3)\end{array}$ & $\begin{array}{c}187.3 \\
(142.7- \\
612.3)\end{array}$ & $\begin{array}{c}313.6 \\
(163.4- \\
621.9)\end{array}$ \\
\hline TNF- $\alpha$ & $\begin{array}{c}129.3 \\
(43.6-2 \mid 2.5)\end{array}$ & $\begin{array}{c}136.9 \\
(38.9-232.8)\end{array}$ & $\begin{array}{c}\text { I433.6 } \\
(54 .|-3| 2.6)\end{array}$ & $\begin{array}{c}\mathbf{2 5 6 . 3}^{d} \\
(115.7- \\
385.4)\end{array}$ & $\begin{array}{c}234.6 \text { e } \\
(114.8- \\
412.6)\end{array}$ & $\begin{array}{c}4 \mid \mathrm{I} .7^{f f} \\
(134.2- \\
532.7)\end{array}$ & $\begin{array}{c}226.4 \\
(89.7-352.7)\end{array}$ & $\begin{array}{c}267.8 \\
(97.3-4 \mid 1.9)\end{array}$ & $\begin{array}{c}320.4 \\
(118.9- \\
543.1)\end{array}$ \\
\hline GM-CSF & $\begin{array}{c}116.1 \\
(55.8-143.7)\end{array}$ & $\begin{array}{c}117.6 \\
(48.3-129.8)\end{array}$ & $\begin{array}{c}135.2 \\
(76.8-176.9)\end{array}$ & $\begin{array}{c}245.1 \mathrm{~g} \\
(76.3-3 \mid 1.1)\end{array}$ & $\begin{array}{c}222.3^{\mathrm{h}} \\
(83.9-288.7)\end{array}$ & $\begin{array}{c}300.8^{i} \\
(123.4- \\
389.8)\end{array}$ & $\begin{array}{c}147.9 \\
(63.6-176.4)\end{array}$ & $\begin{array}{c}132.4 \\
(72.5-166.9)\end{array}$ & $\begin{array}{c}204.1 \\
(89.2-237.1)\end{array}$ \\
\hline
\end{tabular}

Note. Data represents median values (bold). Values in parentheses depict range. All values in pg/ml unless otherwise stated. Along the horizontal axis are the stimulants IncB, IncC and EBs used in cells obtained from GI, GII and GIII and vertical axis are the cytokines secreted in cell cultures assayed using specific ELISAs.

a, b, c P $<0.05$ Level of secreted cytokine in GIII compared to respective levels in groups I and II by Mann Whitney U test.

$\mathrm{d}, \mathrm{e}, \mathrm{f} P<0.0$ I Level of secreted cytokine in Gll compared to respective levels in group I by Mann Whitney $U$ test.

$\mathrm{g}$, h, i P $<0.05$ Level of secreted cytokine in Gll compared to respective levels in groups I and III by Mann Whitney $U$ test.

j, k, I P $<0.05$ Level of secreted cytokine in Gl compared to respected levels in group III by Mann Whitney U test where, Group I (GI) comprised of healthy fertile women with no CT infection, Group II (GII) comprised of CT-positive fertile women.

Group III (GIII) comprised of CT-positive women with fertility disorders. IncB- CT Inclusion membrane protein B; IncC- CT Inclusion membrane protein C; CT- Chlamydia trachomatis; EB-Elementary bodies; IL-Interleukin; $\beta$-Beta; IFN- $\gamma$-Interferon gamma; TNF- $\alpha$-Tumor Necrosis factor alpha; GM-CSF- Granulocyte macrophage colony-stimulating factor

chlamydial infections [57]. In another report, high IL-6 levels have been found to be secreted from CT EB-stimulated cervical cells obtained from CT-positive infertile women [58].

IL-10 was found to be up-regulated in both cervical cells and PBMCs stimulated with incs in CT-positive women with fertility disorders, with levels being significantly higher than CT-positive fertile women and controls. In a previous report on a longitudinal study of genital CT infection, in vitro IL-10 production by PBMCs stimulated with recombinant chlamydial antigens was the greatest risk factor for recurrent infections [59]. In murine models of chlamydial infection, high levels of IL-10 impede pathogen clearance [60], whereas IL-10 mutant mice clear infection faster than genetically intact controls [61-63]. IL10 has been found to be associated with susceptibility to chlamydial infection and typical pathological changes caused by the infection such as granuloma formation and fibrosis [64]. Excessive levels of IL10 levels in conjunctiva are a risk factor for scarring and blindness during CT-associated trachoma. IL-10 contributes to the pathogenesis of fibrotic responses [61,65], and is involved in local matrix remodelling during healing and repair of inflammation- 
Table 5: Cytokine concentrations in culture supernatants of stimulated PBMCs

\begin{tabular}{|c|c|c|c|c|c|c|c|c|c|}
\hline & \multicolumn{3}{|c|}{ GI } & \multicolumn{3}{|c|}{ GII } & \multicolumn{3}{|c|}{ GIII } \\
\hline & IncB & IncC & EBs & IncB & IncC & EBs & IncB & IncC & EBs \\
\hline IL-I $\beta$ & $\begin{array}{l}109.4 \\
(56.7-258.3)\end{array}$ & $\begin{array}{l}119.7 \\
(59.6-324.1)\end{array}$ & $\begin{array}{l}159.9 \\
(73.1- \\
462.69)\end{array}$ & $\begin{array}{l}172.6 \\
(68.4-393.8)\end{array}$ & $\begin{array}{l}183.2 \\
(65.5-407.5)\end{array}$ & $\begin{array}{l}289 \\
(73.1-491.4)\end{array}$ & $\begin{array}{l}413.36^{a} \\
(82.1-786.3)\end{array}$ & $\begin{array}{l}\text { 432.5b } \\
(95.1-729.8)\end{array}$ & $\begin{array}{l}568.9 c \\
(76.4-821.7)\end{array}$ \\
\hline IL-6 & $\begin{array}{l}132.7 \\
(54.3-457.9)\end{array}$ & $\begin{array}{l}146.3 \\
(67.21- \\
547.1)\end{array}$ & $\begin{array}{l}201.65 \\
(87.9- \\
719.82)\end{array}$ & $\begin{array}{l}487.6^{d} \\
(88.86- \\
791.1)\end{array}$ & $\begin{array}{l}473.58 \mathrm{e} \\
(98.6-564.7)\end{array}$ & $\begin{array}{l}\mathbf{6 6 8 f} \\
(121.4- \\
956.8)\end{array}$ & $\begin{array}{l}813.6^{a} \\
(300.2- \\
1421.4)\end{array}$ & $\begin{array}{l}793.45^{b} \\
(312.9- \\
1201.4)\end{array}$ & $\begin{array}{l}1335.47 \mathrm{c} \\
(436.1- \\
1578.3)\end{array}$ \\
\hline IL-IO & $\begin{array}{l}183.4 \\
(106.3- \\
383.6)\end{array}$ & $\begin{array}{l}196.3 \\
(87.3-446.3)\end{array}$ & $\begin{array}{l}328.4 \\
(88.1- \\
612.46)\end{array}$ & $\begin{array}{l}462.7 \\
(189.2- \\
631.3)\end{array}$ & $\begin{array}{l}411.21 \\
(166.8- \\
661.7)\end{array}$ & $\begin{array}{l}\mathbf{5 5 4 . 9} \\
(246-745.2)\end{array}$ & $\begin{array}{l}1005^{a} \\
(414.2- \\
1426.3)\end{array}$ & $\begin{array}{l}956.2^{b} \\
(437.7- \\
1431.6)\end{array}$ & $\begin{array}{l}\text { I472.8c } \\
(336.2- \\
1803)\end{array}$ \\
\hline IL-I 2 & $\begin{array}{l}204.8 \\
(I 13.7- \\
342.7)\end{array}$ & $\begin{array}{l}198.7 \\
(96.8-327.1)\end{array}$ & $\begin{array}{l}342.7 \\
(234.7- \\
515.1)\end{array}$ & $\begin{array}{l}\text { 466.5g } \\
(173.9- \\
712.6)\end{array}$ & $\begin{array}{l}450 . I^{\mathrm{h}} \\
(167.2- \\
572.8)\end{array}$ & $\begin{array}{l}621 . I^{i} \\
(188.3- \\
745.8)\end{array}$ & $\begin{array}{l}167.4 \\
(75.8-3 \mid 2.8)\end{array}$ & $\begin{array}{l}156.8 \\
(88.3-345.8)\end{array}$ & $\begin{array}{l}186.36 \\
(129.3- \\
621.3)\end{array}$ \\
\hline IFN- $\gamma$ & $\begin{array}{l}453.7 \mathrm{i} \\
(88.5-549.3)\end{array}$ & $\begin{array}{l}5 I I .3 k \\
(87.3-631.6)\end{array}$ & $\begin{array}{l}\mathbf{5 7 8 . 8 1} \\
(311.9- \\
714.3)\end{array}$ & $\begin{array}{l}726.6 \mathrm{~g} \\
(351.3- \\
1128.4)\end{array}$ & $\begin{array}{l}671.3^{h} \\
(454.8- \\
1272.5)\end{array}$ & $\begin{array}{l}\mathbf{8 8 4 . 7} \mathbf{i} \\
(557.4- \\
1377.2)\end{array}$ & $\begin{array}{l}241.7 \\
(|42 .-6| 2.3)\end{array}$ & $\begin{array}{l}196.8 \\
(157.6- \\
661.7)\end{array}$ & $\begin{array}{l}263.6 \\
(163.4- \\
721.9)\end{array}$ \\
\hline TNF- $\alpha$ & $\begin{array}{l}\mid 43.6 \\
(54 .|-3| 2.6)\end{array}$ & $\begin{array}{l}156.3 \\
(48.9-331.5)\end{array}$ & $\begin{array}{l}264.2 \\
(127.4- \\
423.7)\end{array}$ & $\begin{array}{l}314.7 d \\
(119.7- \\
523.8)\end{array}$ & $\begin{array}{l}293.6 \text { e } \\
(127.4- \\
623.7)\end{array}$ & $\begin{array}{l}311.7 f \\
(113-452.9)\end{array}$ & $\begin{array}{l}289.9 \\
(97.3-4 \mid 1.9)\end{array}$ & $\begin{array}{l}277.2 \\
(113-452.9)\end{array}$ & $\begin{array}{l}289.3 \\
(125.6- \\
543.7)\end{array}$ \\
\hline GM-CSF & $\begin{array}{l}128.7 \\
(63.4-156.8)\end{array}$ & $\begin{array}{l}136.4 \\
(71.3-149.4)\end{array}$ & $\begin{array}{l}152.4 \\
(89.4-201.1)\end{array}$ & $\begin{array}{l}263.1 \mathrm{~g} \\
(125.3- \\
291.2)\end{array}$ & $\begin{array}{l}248 . I^{\mathrm{h}} \\
(I I I-32 \mid .2)\end{array}$ & $\begin{array}{l}320.4^{i} \\
(136-520)\end{array}$ & $\begin{array}{l}151.2 \\
(76.1-184)\end{array}$ & $\begin{array}{l}163.4 \\
(91.3-201)\end{array}$ & $\begin{array}{l}\mathbf{2 6 8 . 7} \\
(100.1- \\
306.9)\end{array}$ \\
\hline
\end{tabular}

Note. Data represents median values (bold). Values in parentheses depict range. All values in pg/ml unless otherwise stated. Along the horizontal axis are the stimulants IncB, IncC and EBs used in cells obtained from GI, GII and GIII and vertical axis are the cytokines secreted in cell cultures assayed using specific ELISAs.

a, b, c P $<0.05$ Level of secreted cytokine in GIII compared to respective levels in groups I and II by Mann Whitney U test.

$\mathrm{d}, \mathrm{e}, \mathrm{f} P<0.0$ I Level of secreted cytokine in Gll compared to respective levels in group I by Mann Whitney $U$ test.

$\mathrm{g}$, h, i P $<0.05$ Level of secreted cytokine in Gll compared to respective levels in groups I and III by Mann Whitney $U$ test.

j, k, I P $<0.05$ Level of secreted cytokine in Gl compared to respected levels in group III by Mann Whitney $U$ test where, Group I (GI) comprised of healthy fertile women with no CT infection, Group II (GII) comprised of CT-positive fertile women.

Group III (GIII) comprised of CT-positive women with fertility disorders. PBMCs-Peripheral blood mononuclear cells; IncB- CT Inclusion membrane protein B; IncC- CT Inclusion membrane protein C; CT- Chlamydia trachomatis; EBs-Elementary bodies; IL-Interleukin; $\beta$-Beta; IFN- $\gamma$ Interferon gamma; TNF- $\alpha$-Tumor Necrosis factor alpha; GM-CSF- Granulocyte macrophage colony-stimulating factor.

induced injury [66]. Similarly our data suggests that IL-10 over-expression in cells from CT-positive women with fertility disorders could partly contribute to slow or nonclearance of CT resulting in establishment of tubal pathology.

Levels of IFN- $\gamma$ were significantly high in inc-stimulated cells from CT-positive fertile women whereas in CT-positive women with fertility disorders IFN- $\gamma$ was found to be downregulated. Debattista et al., have reported that women with chlamydial PID or a history of repeated CT infection had PBMCs that produced less IFN- $\gamma$ in response to CHSP60 than women with a single episode of CT infection [67]. Subjects with scarring trachoma have shown to produce reduced IFN- $\gamma$ levels during persistent chlamydial infection [52]. Also, co-occurrence of IL-10 and IFN- $\gamma$ producing cells in synovial tissues from CT-positive arthritis patients have suggested that excessive IL-10 production suppresses IFN- $\gamma$ and mediates persistence [68]. These results along with ours suggest a protective role of IFN- $\gamma$ during active chlamydial infection.

Further we detected levels of IL-12 to be significantly higher in inc-stimulated cervical cells and PBMCs from 
Table 6: IFN- $\gamma$ ELISPOT assay in IncB or IncC stimulated $\mathrm{CD4}^{+} \mathrm{T}$ cell cultures

\begin{tabular}{|c|c|c|c|c|c|c|c|c|c|c|c|c|}
\hline & \multicolumn{4}{|c|}{ GI } & \multicolumn{4}{|c|}{ GII } & \multicolumn{4}{|c|}{ GIII } \\
\hline & \multicolumn{2}{|c|}{$\operatorname{lncB}(\mu \mathrm{g} / \mathrm{ml})$} & \multicolumn{2}{|c|}{ IncC ( $\mu \mathrm{g} / \mathrm{ml})$} & \multicolumn{2}{|c|}{$\operatorname{lncB}(\mu \mathrm{g} / \mathrm{ml})$} & \multicolumn{2}{|c|}{ IncC $(\mu \mathrm{g} / \mathrm{ml})$} & \multicolumn{2}{|c|}{$\operatorname{lncB}(\mu \mathrm{g} / \mathrm{ml})$} & \multicolumn{2}{|c|}{ IncC $(\mu \mathrm{g} / \mathrm{ml})$} \\
\hline & 0.5 & 1 & 0.5 & 1 & 0.5 & 1 & 0.5 & 1 & 0.5 & 1 & 0.5 & 1 \\
\hline $\begin{array}{l}\text { Cervical } \\
\text { cells }\end{array}$ & $\begin{array}{c}\text { I I I } \\
(48-2 \mid 4\end{array}$ & $\begin{array}{c}126 \\
(67-263)\end{array}$ & $\begin{array}{c}91 \\
(29-167)\end{array}$ & $\begin{array}{c}142 \\
(43-2 \mid I)\end{array}$ & $\begin{array}{c}132^{\mathbf{a}} \\
(47-3 \mid 2)\end{array}$ & $\begin{array}{c}157^{\mathrm{b}} \\
(56-343)\end{array}$ & $\begin{array}{c}I \mid 2^{c} \\
(38-1 \mid 2)\end{array}$ & $\begin{array}{c}178^{d} \\
(77-329)\end{array}$ & $\begin{array}{c}43 \\
(12-59)\end{array}$ & $\begin{array}{c}49 \\
(12-88)\end{array}$ & $\begin{array}{c}38 \\
(17-63)\end{array}$ & $\begin{array}{c}59 \\
(26-76)\end{array}$ \\
\hline PBMCs & $\begin{array}{c}\mid \mathbf{I} \mathbf{~ I} \\
(38-200)\end{array}$ & $\begin{array}{c}134 \\
(45-2 \mid 2)\end{array}$ & $\begin{array}{c}103 \\
(48-176)\end{array}$ & $\begin{array}{c}172 \\
(44-176)\end{array}$ & $\begin{array}{c}2 \mathbf{I} \mathbf{2}^{\mathbf{a}} \\
(56-273)\end{array}$ & $\begin{array}{c}\mathbf{2 2 6}^{\mathbf{b}} \\
(76-30 \mathrm{I})\end{array}$ & $\begin{array}{c}243^{c} \\
(9 I-322)\end{array}$ & $\begin{array}{c}25 I^{d} \\
(100-3 \mid 6)\end{array}$ & $\begin{array}{c}56 \\
(38-97)\end{array}$ & $\begin{array}{c}67 \\
(43-115)\end{array}$ & $\begin{array}{c}63 \\
(59-108)\end{array}$ & $\begin{array}{c}81 \\
(60-149)\end{array}$ \\
\hline
\end{tabular}

Note. Median number of IFN- $\gamma$ SFCs per $7.5 \times 10^{4} \mathrm{CD}^{+} \mathrm{T}$ cells at $18 \mathrm{~h}$ post stimulation with IncB or IncC $(0.5 \mu \mathrm{g} / \mathrm{ml}$ and I $\mu \mathrm{g} / \mathrm{ml}) \mathrm{counted}$ using ELISPOT. Figures in parenthesis depict range of SFCs for each group.

a, b, c, d P $<0.05$ Number of IFN- $\gamma$ in GII compared to respective levels in group III by Mann Whitney U test where, Group I (GI) comprised of healthy fertile women with no CT infection, Group II (GII) comprised of CT-positive fertile women.

Group III (GIII) comprised of CT-positive women with fertility disorders.

IncB- CT Inclusion membrane protein B; IncC- CT Inclusion membrane protein C; CT- Chlamydia trachomatis; EB-Elementary bodies; IL-Interleukin; IFN- $\gamma$-Interferon gamma; SFCs-Spot forming cells.

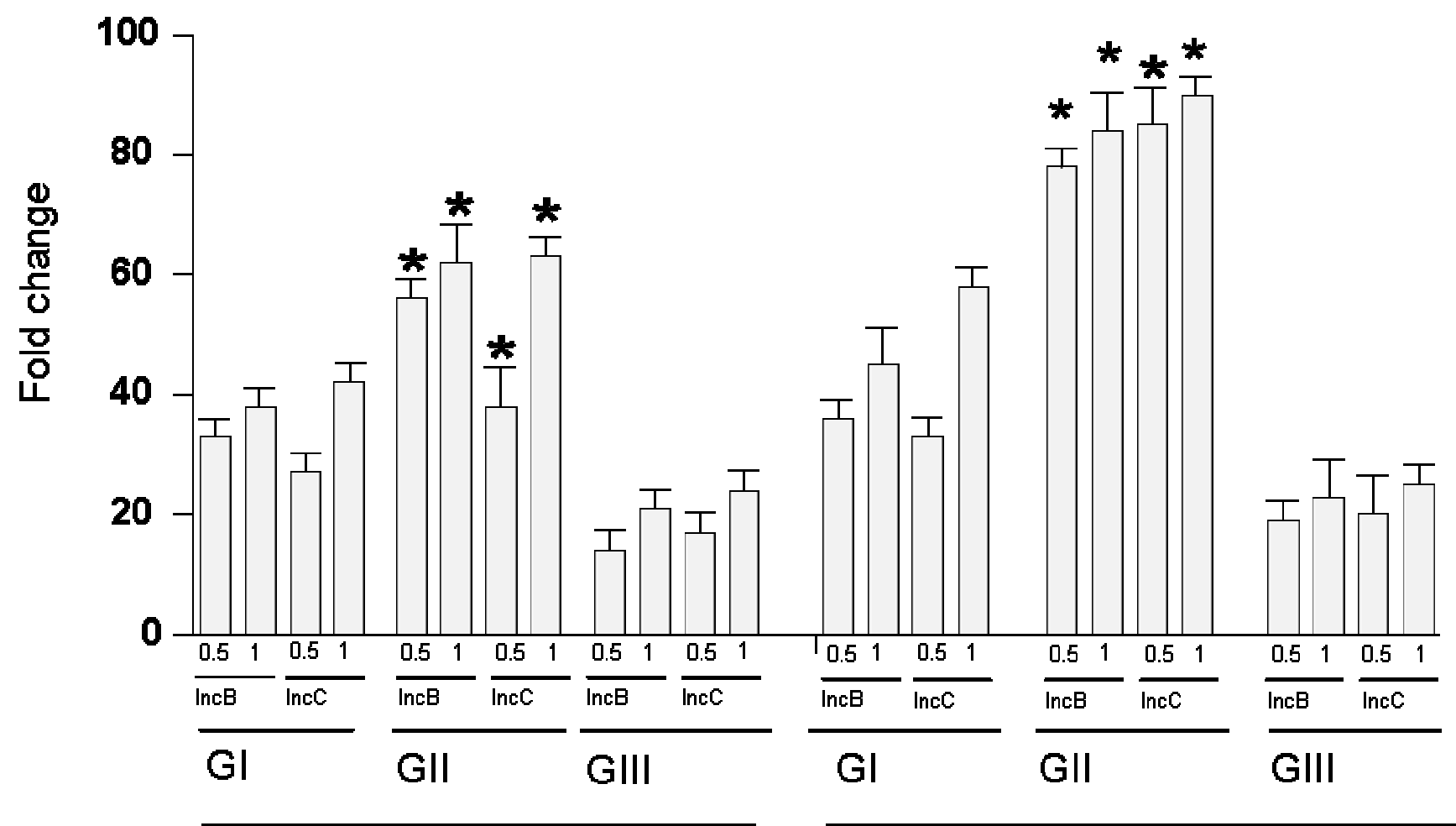

Cervical cells

\section{PBMCs}

\section{Figure 6}

Estimation of IFN- $\gamma$ mRNA relative expression in $7.5 \times 10^{4} \mathrm{CD4}^{+} \mathrm{T}$ cells isolated from cervical cells and PBMCs after in vitro stimulation with IncB or IncC. Real-time RT-PCR analysis of IFN- $\gamma$ mRNA levels was done at 12 hours post stimulation in $\mathrm{CD}^{+} \mathrm{T}$ cells isolated cervical cells and PBMCs isolated from GI, GIl and GIII where, Group I (Gl) comprised of healthy fertile women with no CT infection, Group II (GII) comprised of CT-positive fertile women, Group III (GIII) comprised of CT-positive women with fertility disorders. * $\mathrm{P}<0.05 \mathrm{mRNA}$ expression of IFN- $\gamma$ in Gll compared to respective levels in group III by Mann Whitney $U$ test. All cytokines were normalised against corresponding levels of $\beta$-actin endogenous gene. The graph show results as fold change represented by bars. Bars represent mean \pm s.e.m. for all experiments. 
CT-positive fertile women compared to controls and CTpositive women with fertility disorders. IL- 12 is primarily produced by activated macrophages and dendritic cells and further induces IFN- $\gamma$ production to favour the differentiation of Th1 cells $[69,70]$. Along with TNF- $\alpha$, IL-12 is reported to co-stimulate IFN- $\gamma$ by killer T cells [71]. It has also been previously reported that clearance of chlamydial infection from female adolescents has been associated with decrease in IL-12 concentrations in endocervical samples suggesting its role in protective immune responses against infection [72].

Levels of TNF- $\alpha$ were significantly higher in inc-stimulated cervical cells and PBMCs from CT-positive women with or without fertility related disorders compared to controls. TNF- $\alpha$ is known to inhibit chlamydial growth in vitro [73] and in vivo $[74,75]$. Further, along with IFN- $\gamma$, TNF- $\alpha$ is reported to have implications in infertility $[76,77]$.

Levels of GM-CSF were significantly higher in CT-positive fertile women compared to CT-positive women with fertility disorders and controls. GM-CSF is known to activate macrophages and up-regulate CD14 and MHC class II expression [78], suggesting its role in protective immunity. Further, in a murine model of CT mouse pneumonitis lung infection and intrapulmonary adenoviral GM-CSF transfection, it has been demonstrated that the expression of GM-CSF in the airway compartment significantly enhanced systemic Th1 cellular and local IgA immune responses following immunization with inactivated organisms [79].

A significant finding of this study was the increased mRNA expression levels of IL-4, a classical Th2 marker, in cells obtained from CT-positive women with fertility disorders in comparison to the other two groups. It has previously been reported that individuals with severe trachomatous scarring had PBMCs that produced IL-4 to CHSP60 more frequently than did PBMCs from matched community control subjects without scarring [52]. We failed to detect IL-4 protein levels by ELISA which may be due to the fact IL-4 secreting cells may be quenched or short lived in peripheral circulation or its secretion was downregulated by other factors [52]. Depressed levels of IL-4 has also been detected in CT-infected HIV positive patients using TaqMan $^{\mathrm{TM}}$ based real time PCR [80]. In addition in this study, IL-5 mRNA, another Th2 cytokine was also elevated in the same cell population. Elevated levels of IL-4 and IL5 by splenic lymphocytes from IFN- $\gamma$ knock-out mice following chlamydia-specific has been reported. It was observed that this Th2 mediated delayed hypersensitivity was not protective in controlling local chlamydial infection and associated with serious tissue damage and cellu- lar inflammation and failing to prevent dissemination of the pathogen to other organs in these mice [81].

Overall our data on cytokine modulation in cervical cells and PBMCs on in vitro stimulation with IncB or IncC suggests that CT- negative women who encounter chlamydial antigens for the first time and CT-positive fertile women produce higher amounts of IFN- $\gamma$, IL-12 and GM-CSF than in women with reproductive sequalae to chlamydial infection where the infected cells secrete higher levels of IL-1 $\beta$, IL-4, IL-5, IL-6 and IL-10.

In addition $\mathrm{CD}^{+} \mathrm{T}$ cells in CT-positive women with and without fertility disorders displayed high levels of IFN- $\gamma$ secreting cells and mRNA expression and minimal IL-4 production upon in vitro dose-dependent stimulation with IncB and IncC, demonstrating the induction of an antigen-specific Th1 cellular response. There is accumulated evidence to suggest that Th1 responses and IFN- $\gamma$ production are important for optimal resolution of genital chlamydial infection $[2,3]$. It has also been demonstrated that Chlamydia-specific Th1 clones, but not Th2 clones, are capable of adoptively transferring anti-chlamydial immunity [82-84], and that MHC class II deficient, but not MHC class I deficient animals were incapable of resolving a primary chlamydial challenge [85]. Thus, our data shows that IncB and IncC could be able to mount a protective Th1 cellular response for clearance of CT from infected host cells. Although it would be presumptuous to assume that the clinical condition of women with fertility disorders could be completely attributed to chlamydial infections yet it is not wrong to say that the changes in cytokine patterns can be responsible for development of various pathological consequences to chlamydial infection. Further, to this end the role of IncB and IncC in maintaining a differential cytokine surveillance milieu within infected cells is of interest. As chlamydial inclusion proteins are involved in biochemical cross-talk between host cells and infecting pathogens, hence the overall data on host immune responses to these proteins would be helpful in further understanding of biological functioning of this elusive pathogen.

\section{Conclusion}

The intent of the study was to provide insights into the role of chlamydial inclusion membrane proteins in generating immunity in host cells and their probable contribution to the disease processes associated with chlamydial infections. This study suggested that the chlamydial IncB and IncC are able to generate differential humoral and cell mediated immune responses in Chlamydia- infected women with or without fertility disorders. Further research is warranted to precisely define the potential contribution of chlamydial incs in immunopathology associated with chlamydial infection. 


\section{Competing interests}

The authors declare that they have no competing interests.

\section{Authors' contributions}

AM and RG had participated in the design of the study. The experiments were carried out by RG. PS and HV had assisted in Western blotting experiments. Data analysis was performed by RG. SS and PS had helped in collection of samples. AM and RG drafted and wrote the manuscript. All authors have read and approved the final manuscript.

\section{Acknowledgements}

We are highly grateful to Dr. Guangming Zhong at Department of Microbiology and Immunology, University of Texas Health Science Center at San Antonio, 7703 Floyd Curl Drive, San Antonio, Texas 78229, USA for kindly providing recombinant expression vector clones of chlamydial inclusion proteins B and C. We are thankful to Mrs. Madhu Badhwar, Mrs. Asha Rani and Mrs. Rosamma Thomas, for providing technical assistance during the study. This study was supported by grants (BT/IN/USCRHR/AM/2002) and (BT/PR 4643/MED/I2/I77/2004) from the Department of Biotechnology, Government of India. University Grants Commission is acknowledged for providing assistance to Rishein Gupta as fellowship. Indian Council of Medical Research is acknowledged for providing assistance to Pragya Srivastava and Harsh Vardhan in the form of fellowship.

\section{References}

I. Beagley KW, Timms P: Chlamydia trachomatis infection: incidence, health costs and prospects for vaccine development. J Reprod Immunol 2000, 48:47-68.

2. Brunham RC, Rey-Ladino J: Immunology of Chlamydia infection: implications for a Chlamydia trachomatis vaccine. Nat Rev Immunol 2005, 5:|49-16I.

3. Morrison RP, Caldwell HD: Immunity to murine chlamydial genital infection. Infect Immun 2002, 70:274I-275I.

4. Gerbase AC, Rowley JT, Heymann DHL, Berkley SFB, Piot P: Global prevalence and incidence estimates of selected curable STDs. Sex Transm Infect 1998, 74(SuppI I):SI2-SI6.

5. Wolf K, Hackstadt T: Sphingomyelin trafficking in Chlamydia pneumoniae - infected cells. Cell Microbiol 200I, 3:145-I52.

6. Beatty WL: Trafficking from CD63-positive late endocytic multivesicular bodies is essential for intracellular development of Chlamydia trachomatis. J Cell Sci 2006, I 1 9:350-359.

7. Brummel JH, Scidmore MA: Manipulation of Rab GTPase function by intracellular bacterial pathogens. Microbiol Mol Biol Rev 2007, 71:636-652.

8. Delevoye C, Nilges M, Dehoux P, Paumet F, Perrinet S, Dautry-Varsat A, Subtil A: SNARE Protein Mimicry by an Intracellular Bacterium. PLoS Pathog 2008, 4(3): el 000022.

9. Subtil A, Parsot C, Dautry-Varsat A: Secretion of predicted Inc proteins of Chlamydia pneumoniae by a heterologous type III machinery. Mol Microbiol 200I, 39:792-800.

10. Rockey DD, Alzhanov DT: Proteins in the Chlamydial inclusion membrane. In Chlamydia: genomics and pathogenesis Edited by: Bavoil PM, Wyrick PB. Norfolk, Horizon Bioscience; 2006:235-254.

II. Rockey DD, Grosenbach D, Hruby DE, Peacock MG, Heinzen RA, Hackstadt T: Chlamydia psittaci IncA is phosphorylated by the host cell and is exposed on the cytoplasmic face of the developing inclusion. Mol Microbiol 1997, 24:217-228.

12. Scidmore MA, Hackstadt T: Mammalian 14-3-3 $\beta$ associates with the Chlamydia trachomatis inclusion membrane via its interaction with IncG. Mol Microbiol 200I, 39:1638-1650.

13. Bannantine JP, Stamm WE, Suchland RJ, Rockey DD: Chlamydia trachomatis IncA is localized to the inclusion membrane and is recognized by antisera from infected humans and primates. Infect Immun 1998, 66:6017-602I.

14. Li Z, Chen C, Chen D, Wu Y, Zhong Y, Zhong G: Characterization of 50 putative inclusion membrane proteins encoded in
Chlamydia trachomatis genome. Infect Immun 2008, 76:2746-2757.

15. Rockey DD, Heinzen RA, Hackstadt T: Cloning and characterization of a Chlamydia psittaci gene coding for a protein localized in the inclusion membrane of infected cells. Mol Microbiol 1995, 15:617-626.

16. Bannantine JP, Rockey DD, Hackstadt T: Tandem genes of Chlamydia psittaci that encode proteins localized to the inclusion membrane. Mol Microbiol 1998, 28:1017-1026.

17. Scidmore-Carlson MA, Shaw El, Dooley CA, Fischer ER, Hackstadt T: Identification and characterization of a Chlamydia trachomatis early operon encoding four novel inclusion membrane proteins. Mol Microbiol 1999, 33:753-765.

18. Wizel B, Starcher BC, Samten B, Chroneos Z, Barnes PF, Dzuris J, Higashimoto Y, Appella E, Sette A: Multiple Chlamydia pneumoniae antigens prime $\mathrm{CD8}^{+} \mathrm{Tcl}$ responses that inhibit intracellular growth of this vacuolar pathogen. J Immunol 2002, 169:2524-2535.

19. Fling SP, Sutherland RA, Steele LN, Hess B, D'Orazio SE, Maisonneuve J, Lampe MF, Probst $P$, Starnbach MN: $C^{2} 8^{+} T$ cells recognize an inclusion membrane-associated protein from the vacuolar pathogen Chlamydia trachomatis. Proc Natl Acad Sci USA 200I, 98: $1160-1165$.

20. Starnbach MN, Loomis WP, Ovendale P, Regan D, Hess B, Alderson MR, Fling SP: An inclusion membrane protein from Chlamydia trachomatis enters the MHC class I pathway and stimulates a CD8+T cell response. J Immunol 2003, I 7 I:4742-4749.

21. Delevoye C, Nilges M, Dautry-Varsat A, Subtil A: Conservation of the biochemical properties of IncA from Chlamydia trachomatis and Chlamydia caviae: oligomerization of IncA mediates interaction between facing membranes. J Biol Chem 2004, 279:46896-46906.

22. Xia M, Suchland RJ, Bumgarner RE, Peng T, Rockey DD, Stamm WE: Chlamydia trachomatis variant with nonfusing inclusions: growth dynamic and host-cell transcriptional response. J Infect Dis 2005, 192: 1229-1236.

23. Shirai M, Hirakawa H, Kimoto M, Tabuchi M, Kishi F, Ouchi K, Shiba T, Ishii K, Hattori M, Kuhara S, Nakazawa T: Comparison of whole genome sequences of Chlamydia pneumoniae J138 from Japan and CWL029 from USA. Nucleic Acids Res 2000, 28:23||-23|4.

24. Read TD, Brunham RC, Shen C, Gill SR, Heidelberg JF, White O, Hickey EK, Peterson J, Utterback T, Berry K, Bass S, Linher K, Weidman J, Khouri H, Craven B, Bowman C, Dodson R, Gwinn M, Nelson W, DeBoy R, Kolonay J, McClarty G, Salzberg SL, Eisen J, Fraser CM: Genome sequences of Chlamydia trachomatis MoPn and Chlamydia pneumoniae AR39. Nucleic Acids Res 2000, 28:1397-1406.

25. Thomson NR, Yeats C, Bell K, Holden MTG, Bentley SD, Livingstone $M$, Cerdeno-Tarraga AM, Harris B, Doggett J, Ormond D, Mungall K, Clarke K, Feltwell T, Hance Z, Sanders M, Quail MA, Price C, Barrell BG, Parkhill J, Longbottom D: The Chlamydophila abortus genome sequence reveals an array of variable proteins that contribute to interspecies variation. Genome Res 2005, I 5:629-640.

26. Bannantine JP, Griffiths RS, Viratyosin W, Brown WJ, Rockey DD: A secondary structure motif predictive of protein localization to the chlamydial inclusion membrane. Cell Microbiol 2000, 2:35-47.

27. Toh H, Miura K, Shirai M, Hattori M: In silico inference of inclusion membrane protein family in obligate intracellular parasites chlamydiae. DNA Res 2003, 10:9-17.

28. Horn M, Collingro A, Schmitz-Esser S, Beier CL, Purkhold U, Fartmann B, Brandt P, Nyakatura G], Droege M, Frishman D, Rattei T, Mewes HW, Wagner M: Illuminating the evolutionary history of Chlamydiae. Science 2004, 304:728-730.

29. Azuma $Y$, Hirakawa H, Yamashita A, Cai $Y$, Rahman MA, Suzuki H, Mitaku S, Toh H, Goto S, Murakami T, Sugi K, Hayashi H, Fukushi H, Hattori M, Kuhara S, Shirai M: Genome sequence of the cat pathogen, Chlamydophila felis. DNA Res 2006, 13:15-23.

30. Vretou E, Katsiki E, Psarrou E, Vougas K, Tsangaris GT: Identification and characterization of Inc766, an inclusion membrane protein in Chlamydophila abortus-infected cells. Microb Pathog. 2008, 45(4):265-272.

31. Li ZY, Wu YM, Hunag Q, Wang S, Zhong G: Localization and characterization of Hypothetical Protein CT358 in the 
Chlamydia trachomatis-infected cells. Prog Biochem Biophy 2009 [http://www.pibb.ac.cn/cn/ch/common/ create pdf.aspx?file no $=20080109 \&$ flag $=1]$

32. Gupta R, Salhan S, Mittal A: Seroprevalence of antibodies against Chlamydia trachomatis Inclusion membrane proteins B and C in infected symptomatic women. J Infect Developing Countries 2009 in press.

33. Reddy BS, Rastogi S, Das B, Salhan S, Verma S, Mittal A: Cytokine expression pattern in the genital tract of Chlamydia trachomatis positive infertile women - implication for T-cell responses. Clin Exp Immunol 2004, 137:552-558.

34. George JA, Panchatcharam TS, Paramasivam R, Balasubramaniam $S$, Chakrapani V, Murugan G: Evaluation of diagnostic efficacy of PCR methods for Chlamydia trachomatis infection in genital and urine specimens of symptomatic men and women in India. Jpn J Infect Dis 2003, 56:88-92.

35. Kostrjukova ES, Lazarev VN, Titova GA, Akopian TA, Levitskii SA Govorun VM: Expression of Chlamydia trachomatis Inclusion Membrane Protein Genes IncB and IncC in Escherichia coli. Biochem (Mosc) 2006, 7I:262-269.

36. Sharma J, Zhong Y, Dong F, Piper JM, Wang G, Zhong G: Profiling of Human antibody responses to Chlamydia trachomatis Urogenital Tract Infection using Microplates Arrayed with 156 Chlamydial Fusion Proteins. Infect Immun 2006, 74: I490- I 499.

37. Dutta R, Jha R, Gupta S, Gupta R, Salhan S, Mittal A: Seroprevalence of anti-bodies to conserved regions of Chlamydia trachomatis heat shock proteins 60 and 10 in women in India. $\mathrm{Br} J$ Biomed Sc 2007, 64:78-83.

38. Agrawal T, Vats $V$, Salhan S, Mittal A: Mucosal and peripheral immune responses to chlamydial heat shock proteins in women infected with Chlamydia trachomatis. Clin Exp Immunol 2007, I 48:46| -468.

39. Mittal A, Kapur S, Gupta S: Chlamydial cervicitis: role of culture, enzyme immunoassay and Giemsa cytology in diagnosis. APMIS 1993, I01:37-40.

40. Jasper MJ, Tremellen KP, Robertson SA: Primary unexplained infertility is associated with reduced expression of the T-regulatory cell transcription factor Foxp3 in endometrial tissue. Mol Hum Reprod 2006, I 2:301-308.

41. Livak KJ, Schmittgen TD: Analysis of relative gene expression data using real- time quantitative PCR and the 2(-Delta Delta C(T))method. Methods 200I, 25:402-8.

42. Hackstadt T, Scidmore-Carlson MA, Shaw El, Fischer ER: The Chlamydia trachomatis IncA protein is required for homotypic vesicle fusion. Cell Microbiol I999, I: I 19-130.

43. Scidmore-Carlson MA, Shaw El, Dooley CA, Fischer ER, Hackstadt T: Identification and characterization of a Chlamydia trachomatis early operon encoding four novel inclusion membrane proteins. Mol Microbiol I 999, 33:753-765.

44. Shaw J, Grund V, Durling L, Crane D, Caldwell HD: Dendritic cells pulsed with a recombinant chlamydial major outer membrane protein antigen elicit a CD4 ${ }^{+}$type 2 rather than type I immune response that is not protective. Infect Immun 2002, 70:1097-1105.

45. Srivastava $P$, Jha $R$, Bas $S$, Salhan $S$, Mittal $A$ : In Infertile women, cells from Chlamydia trachomatis infected site release higher levels of interferon- gamma, interleukin-10 and tumor necrosis factor-alpha upon heat shock protein stimulation than fertile women. Reprod Biol Endocrinol. 2008, 6:20.

46. Kinnunen A, Surcel HM, Halttunen M, Tiitinen A, Morrison RP, Morrison SG, Koskela P, Lehtinen M, Paavonen J: Chlamydia trachomatis heat shock protein-60 induced interferon-gamma and interleukin- 10 production in infertile women. Clin Exp Immunol 2003, I 31:299-303.

47. Gaur LK, Peeling RW, Cheang M, Kimani J, Bwayo J, Plummer F, Brunham RC: Association of Chlamydia trachomatis heat-shock protein $\mathbf{6 0}$ antibody and HLA Class II DQ alleles. I Infect Dis 1999, 180:234-237.

48. Peeling RW, Bailey RL, Conway DJ, Holland MJ, Campbell AE, Jallow $\mathrm{O}$, Whittle HC, Mabey DC: Antibody response to the $60-\mathrm{kDa}$ chlamydial heat- shock protein is associated with scarring trachoma. J Infect Dis 1998, I77:256-259.

49. Eckert LO, Hawes SE, Wölner-Hanssen P, Money DM, Peeling RW, Brunham RC, Stevens CE, Eschenbach DA, Stamm WE: Prevalence and correlates of antibody to chlamydial heat shock protein in women attending sexually transmitted disease clinics and women with confirmed pelvic inflammatory disease. J Infect Dis 1997, I75: | 453-|458.

50. Peeling RW, Patton DL, Cosgrove Sweeney YT, Cheang MS, AB Lichtenwalner, Brunham RC, Stamm WE: Antibody response to the chlamydial heat-shock protein 60 in an experimental model of chronic pelvic inflammatory disease in monkeys (Macaca nemestrina). J Infect Dis 1999, 180:774-779.

5I. Holland MJ, Bailey RL, Hayes LJ, Whittle HC, Mabey DCW: Conjunctival scarring in trachoma is associated with depressed cell mediated immune responses to Chlamydia antigens. Infect Dis 1993, 168:1528-1531.

52. Holland MJ, Bailey RL, Conway DJ, Culley F, Miranpuri G, Byrne GI: Thelper type-I (ThI)/Th2 profiles of peripheral blood mononuclear cells (PBMC) responses to antigens of Chlamydia trachomatis in subjects with severe trachomatous scarring. Clin Exp Immunol 1996, 105:429-435.

53. Alzhanov DT, Weeks SK, Burnett JR, Rockey DD: Cytokinesis is blocked in mammalian cells transfected with Chlamydia trachomatis gene CT223. BMC Microbiol 2009, 9:2.

54. Hvid M, Baczynska A, Deleuran B, Fedder J, Knudsen HJ, Christiansen G, Birkelund S: Interleukin-I is the initiator of fallopian tube destruction during Chlamydia trachomatis infection. Cell Microbiol 2007, 9:2795-2803.

55. Gerard HC, Wang Z, Whittum-Hudson JA, El-Gabalawy H, Goldbach-Mansky R, Bardin T, Schumacher HR, Hudson AP: Cytokine and chemokine mRNA produced in synovial tissue chronically infected with Chlamydia trachomatis and C. pneumoniae. | Rheumatol 2002, 29: | 827-1835.

56. $Y u$ JL, Yu $P, L i$ LX: HeLa cells secrete interleukin-8 and interlukin- 10 response to Chlamydia trachomatis entry. Hunan $Y_{i} \mathrm{Ke}$ Da Xue Xue Bao 2003, 2: I74-6.

57. Li H, Liang Z: Determination of tumour-necrosis factor-alpha and interleukin-6 levels of the tubal fluids in patients with infertility caused by infection of Chlamydia trachomatis. Zhonghua Fu Chan Ke Za Zhi 2000, 35:4II-2.

58. Agrawal T, Gupta R, Dutta R, Srivastava P, Bhengraj AR, Salhan S, Mittal A: Protective or pathogenic immune response to genital chlamydial infection in Women-A possible role of cytokine secretion profile of cervical mucosal cells. Clin Immunol 2009, 130:347-54

59. Cohen CR, Koochesfahani KM, Meier AS, Shen C, Karunakaran K, Ondondo B, Kinyari T, Mugo NR, Nguti R, Brunham RC: Immunoepidemiologic profile of Chlamydia trachomatis infection: importance of heat-shock protein 60 and interferongamma. J Infect Dis 2005, 192:591-599.

60. Yang X, Gartner J, Zhu L, Wang S, Brunham RC: IL- 10 gene knockout mice show enhanced ThI-like protective immunity and absent granuloma formation following Chlamydia trachomatis lung infection. J Immunol 1999, 162:1010-1017.

61. Yang X, HayGlass KT, Brunham RC: Genetically determined differences in IL- 10 and IFN-gamma responses correlate with clearance of Chlamydia trachomatis mouse pneumonitis infection. I Immunol 1996, I 56:4338-4344.

62. Redpath S, Ghazal P, Gascoigne NR: Hijacking and exploitation of IL-I 0 by intracellular pathogens. Trends Microbiol 200I, 9:86-92.

63. Igietseme JU, Ananaba GA, Bolier J, Bowers S, Moore T, Belay T, Eko FO, Lyn D, Black CM: Suppression of endogenous IL-IO gene expression in dendritic cells enhances antigen presentation for specific Thl induction: potential for cellular vaccine development. J Immunol 2000, 164:42I2-42I9.

64. Conti P, Kampuraj D, Kandere K, DiGioacchino M, Barbacane RC Castellani ML, Felaco M, Boucher W, Letourneau R, Theoharides TC: IL-10, an inflammatory/inhibitory cytokine but not always. Immunol Lett 2003, 86:123-129.

65. Barbarin V, Xing Z, Delos M, Lison D, Huaux F: Pulmonary overexpression of IL- 10 augments lung fibrosis and Th2 responses induced by silica particles. Am J Physiol Lung Cell Mol Physiol 2005, 288:L84I-8.

66. Lee CG, Homer RJ, Cohn L, Link H, Jung S, Craft JE, Graham BS, Johnson TR, Elias JA: Transgenic overexpression of interleukin (IL)10 in the lung causes mucus metaplasia, tissue inflammation, and airway remodeling via IL- I3-dependent and -independent pathways. J Biol Chem 2002, 277:35466-35474.

67. Debattista J, Timms P, Allan J: Reduced levels of gamma-interferon secretion in response to chlamydial $60 \mathrm{kDa}$ heat shock protein amongst women with pelvic inflammatory disease 
and a history of repeated Chlamydia trachomatis infections. Immunol Lett 2002, 81:205-210.

68. Kotake S, Schumacher HR Jr, Arayssi TK, Gérard HC, Branigan PJ, Hudson AP, Yarboro CH, Klippel JH, Wilder RL: Gamma-interferon and interleukin- 10 gene expression in synovial tissues from patients with early stages of Chlamydia-associated arthritis and undifferentiated oligoarthritis and from healthy volunteers. Infect Immun 1999, 67:2682-2686.

69. Trinchieri G: Interleukin- 12 and the regulation of innate resistance and adaptive immunity. Nat Rev Immunol 2003, 3: I33-146.

70. Heufler C, Koch F, Stanzl U, Topar G, Wysocka M, Trinchieri G, Enk A, Steinman RM, Romani N, Schuler G: Interleukin- 2 is produced by dendritic cells and mediates $T$ helper I development as well as interferon-gamma production by $\mathrm{T}$ helper I cells. Eur J Immunol 1996, 26:659-668.

71. Tripp CS, Wolf SF, Unanue ER: Interleukin I 2 and tumor necrosis factor a are costimulators of interferon-gamma production by natural killer cells in severe combined immunodeficiency mice with listeriosis and interlukin- 10 is a physiologic antagonist. Proc Natl Acad Sci USA 1993, 90:3725-3729.

72. Wang C, Tang J, Crowley-Nowick PA, Wilson CM, Kaslow RA, Geisler WM: Interleukin (IL)-2 and IL-I 2 responses to Chlamydia trachomatis infection in adolescents. Clin Exp Immunol 2005, I 42:548-554.

73. Shemer-Avni $Y$, Wallach D, Sarov I: Inhibition of Chlamydia trachomatis growth by recombinant tumor necrosis factor. Infect Immun 1 988, 56:2503-2506.

74. Williams DM, Magee DM, Bonewald LF, Smith JG, Bleicker CA, Byrne $\mathrm{Gl}$, Schachter J: A role in vivo for tumor necrosis factor alpha in host defense against Chlamydia trachomatis. Infect Immun 1990, 58:1572-1576.

75. Perry LL, Su H, Feilzer K, Messer R, Hughes S, Whitmire W, Caldwell HD: Differential sensitivity of distinct Chlamydia trachomatis isolates to IFN- $\gamma$-mediated inhibition. J Immunol 1999, I 62:354|-3548.

76. Darville T, Andrews CW Jr, Rank RG: Does inhibition of tumor necrosis factor alpha affect chlamydial genital tract infection in mice and guinea pigs? Infect Immun 2000, 68:5299-5305.

77. Naz RK, Butler A, Witt BR, Barad D, Menge AC: Levels of interferon-gamma and tumor necrosis factor-alpha in sera and cervical mucus of fertile and infertile women: implication in infertility. J Reprod Immunol 1995, 29: 105-I I7.

78. Caulfield Jj, Hawrylowicz CM, Kemeny DM, Lee TH: GM-CSF increases the ability of cultured macrophages to support autologous $\mathrm{CD4}^{+} \mathrm{T}$-cell proliferation in response to Dermatophagoides pteronyssinus and PPD antigen. Immunology 1997, 92: $123-130$.

79. Lu H, Xing Z, Brunham RC: GM-CSF Transgene-Based Adjuvant Allows the establishment of Protective Mucosal Immunity Following Vaccination with inactivated Chlamydia trachomatis. J Immunol 2002, 169:6324-633I.

80. Scott ME, Yifei M, Farhat S, Shiboski S, Moscicki AB: Covariates of cervical cytokine mRNA expression by real-time PCR in adolescent and young women: effect of Chlamydia trachomatis infection, hormonal contraception, and smoking. J Clin Immunol 2006, 26:222-232.

8I. Wang S, Fan S, Brunham RC, Yang X: IFN- $\gamma$ knockout mice show Th2- associated delayed-type hypersensitivity and the inflammatory cells fail to localize and control chlamydial infection. Eur J Immunol 1999, 29:3782-3792.

82. Igietseme JU, Magee DM, Williams DM, Rank RG: Role for CD8+ $\mathbf{T}$ cells in antichlamydial immunity defined by Chlamydia-specific T-lymphocyte clones. Infect Immun 1994, 62:5 I 95-5 I97.

83. Igietseme JU, Ramsey KH, Magee DM, Williams DM, Kincy T], Rank RG: Resolution of murine chlamydial genital infection by the adoptive transfer of a biovar-specific, Th I lymphocyte clone. Reg Immunol 1993, 5:3 I7-324.

84. Ramsey KH, Rank RG: Resolution of chlamydial genital infection with antigen-specific T-lymphocyte lines. Infect Immun |991, 59:925-931.

85. Williams DM, Grubbs BG, Pack E, Kelly K, Rank RG: Humoral and cellular immunity in secondary infection due to murine Chlamydia trachomatis. Infect Immun 1997, 65:2876-2882.

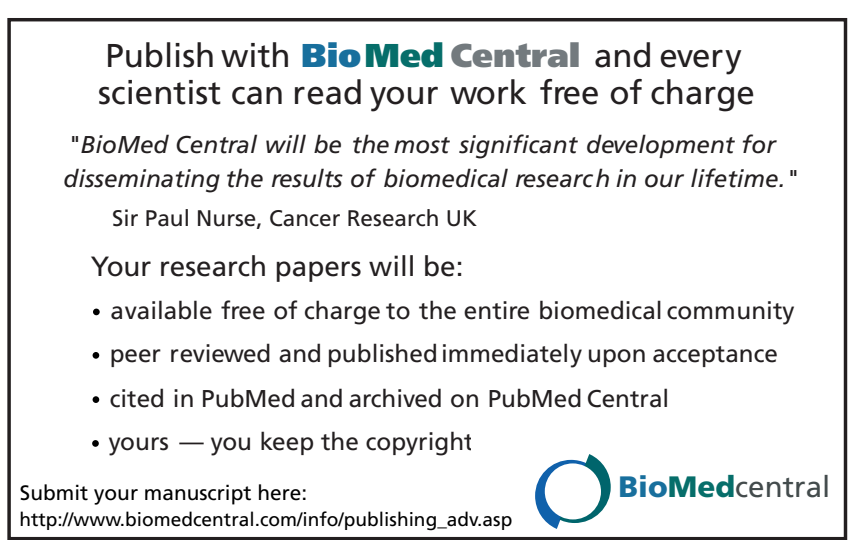

